\title{
Mapping DNAPL Transport and Contamination in Sedimentary and Fractured Rock Aquifers with High Resolution Borehole Seismic Imaging Project No. SF11SS13 \\ FY01 Annual Report
}

\author{
J. T. Geller and E. L. Majer, Principal Investigators \\ with J. E. Peterson, K. H. Williams and S. Flexser \\ Earth Sciences Division, E. O. Lawrence Berkeley National Laboratory
}

December, 2001

This work was supported by the Director, Office of Energy Research, Office of Health and Environmental Sciences, Biological and Environmental Research Program, of the U.S. Department of Energy under Contract no. DE-AC03-7 


\section{Executive Summary}

The objectives of this project are to develop, demonstrate and evaluate, at appropriate field sites, the utility of high frequency seismic imaging methods to detect and characterize non-aqueous phase liquid (NAPL) contamination in sedimentary and fractured rock aquifers. Seismic methods may significantly reduce the final cost of remediation by accurately targeting source areas. Our field work for FY01 was performed at the Northeast Site of the Pinellas Science, Technology, and Research (STAR) Center, in Largo, Pinellas County, Florida. The STAR Center is a former DOE facility that manufactured neutron generators and other electronic and mechanical components for nuclear weapons from 1956 to 1994, and is now owned by Pinellas County, with DOE maintaining responsibility for site remediation. Waste and construction debris were disposed of at Northeast site in the 1950s through 1960s. The site is contaminated by volatile organic chemicals (VOCs), including NAPL tricholorethylene (TCE), toluene, methylene chloride, and weathered oils and perhaps resins.

The Northeast Site is underlain by a surficial aquifer composed of a heterogeneous distribution of beachtype deposits, including fine sands with variable shell content, and silty and clayey sands. The water table depth is about two meters below ground surface and the surficial aquifer is approximately $9 \mathrm{~m}$ deep. The Hawthorn Group, a 18 to $21 \mathrm{~m}$ thick confining layer, lies below the surficial aquifer. The Hawthorn consists of silty-clay with gravel, silty-sandy phosphatic clay and carbonaceous clay with friable carbonate layers. Below the Hawthorn Group is the Floridian Aquifer, a limestone formation, which is an important regional groundwater resource. VOC contamination occurs within the surficial aquifer and at its contact with the Hawthorn.

Laboratory granulametric and geophysical analyses were performed on grab samples donated by the site that were taken from various depths within the surficial aquifer. All of the samples were fine-grained or smaller, having an occasional pebble; one sample had significant shell content. Clay fractions of six samples from the surficial aquifer and from the Hawthorn unit were analyzed. In five of the aquifer samples, the clay fraction was mostly kaolinite. One sample from $3 \mathrm{~m}$ depth had a significant amount of smectite (an expandable clay) and Hawthorne unit sample was smectite, possibly combined with chlorite. One sample from about $6 \mathrm{~m}$ deep, having a median grain diameter $150 \mu \mathrm{m}$, was used to measure P-wave transmission as a function of water/TCE saturation. P-wave velocities declined as a function of TCE saturation, consistent with previous studies, however the amplitude change was much less. This is significant, because P-wave attenuation could be a helpful diagnostic for NAPL detection. The minimal attenuation observed in this experiment may be due to either the lower reflectivity between TCE and water compared to other NAPL-water pairs, and/or the relatively small grain size of the sample. Of the NAPLs presumed to be present at the site, the reflectivity between toluene, resins and water is almost an order of magnitude greater than for TCE and water, which may mean that attenuation through these NAPLs would be greater. Testing in FY02 will investigate the relationships between seismic attributes and various NAPLs in intact core from the site.

High-frequency seismic and radar cross-hole surveys were performed in several locations at the site. Eleven 2" diameter boreholes were installed to a depth of approximately $10 \mathrm{~m}$ (extending into the Hawthorn unit) with a cone penetration test (CPT) rig and cased with blank PVC. Four lines of two or three boreholes were installed. Within each line, the boreholes were spaced about $2.3 \mathrm{~m}$ apart. One line of three boreholes was located in the northern area of the site, where NAPL contamination has been detected. Two lines of three boreholes each were located in the southern area of the site where NAPL has been detected, and one line of two boreholes was located in the southern part of the site where no NAPL had been detected. A CPT log was collected in one borehole in each line. Electrical conductivity logs were measured in all boreholes. Cross-hole seismic data were collected for six borehole pairs, to yield at least one tomogram at each transect location. The dominant frequency range for the seismic data was $3-5 \mathrm{kHz}$, but $1-2 \mathrm{kHz}$ was also visible; velocities ranged from 1800 to $2200 \mathrm{~m} / \mathrm{s}$. These transmission characteristics suggest that wavelengths on the order of 30 to $70 \mathrm{~cm}$ are achievable at the site. Cross-hole radar data were collected for three borehole pairs, and zero-offset (horizontal transmission only) data were acquired for another three pairs. In the first two boreholes, radar tomograms were acquired using borehole antennas having a central 
frequency of approximately $100 \mathrm{MHz}$. Due to the good radar transmission at $100 \mathrm{MHz}$, the rest of the measurements were made with $200 \mathrm{MHz}$.

Preliminary processing of the cross-hole data indicated that the boreholes were significantly deviated from vertical orientation. A deviation survey to determine the $x-y-z$ coordinates along the depth of the boreholes was performed, and this information was used in the final tomographic inversions of the cross-hole data. Due to either extreme deviations or possible inaccuracies in the deviation survey, the velocity distributions in the tomograms were dominated by geometric effects and provided minimal reliable information. Without the horizontal discretization provided by tomography, much of the information that could potentially be derived from the data collected cannot be utilized.

This first field test provides important information regarding the seismic and radar transmission properties of the Northeast site, general geological structure, and a measure of the extent of heterogeneity between the different locations surveyed. The zero-offset seismic and radar cross-hole data, and the CPT and borehole electrical conductivity logs provide consistent and complementary information. They indicate similar structure in the south NAPL area, except for a zone that was disturbed by an earlier remediation trial with rotary steam drilling. The seismic measurements detect some formation changes that do not appear in the CPT-derived lithology, however, for the most part they do correspond to fluctuations in the CPT pressure logs. The higher frequency seismic data $(3-5 \mathrm{kHz})$ reveal some features that are not differentiated in lower frequency data $(1-2 \mathrm{kHz})$. Low amplitude seismic zones appear fairly consistently at around 7.5 to $8 \mathrm{~m}$ depth. First arrivals were not detectable in parts of these zones, which resulted in poor ray coverage and inability to resolve velocity distributions. There is another low amplitude zone at about $4 \mathrm{~m}$ depth. The low amplitude may be due to the attenuating nature of the layer itself, or the transition between two distinct layers. The CPT data do indicate lithology changes in these zones. The presence of lithologic contrasts, specifically from higher pemeability sands to lower permeability silts and clays, also indicate potential locations of NAPL, as they could be flow barriers to downward NAPL migration.

High seismic amplitudes were encountered below 8 to $9 \mathrm{~m}$ depth, where clays are indicated by the CPT logs. This is surprising, given that clays are often very attenuating to high frequency seismic energy. Geologic logs in the areas of the surveys note the presence of carbonate inclusions, gravel and carbonate layers in these clays below $10 \mathrm{~m}$ depth. There are also observations of weathered limestone/clay/shells and phosphate, and sandy clay where the sand is very fine, slightly hard and brittle.

Radar transmission also declines through the low seismic amplitude zone at 7.5 to $8 \mathrm{~m}$ depth, but does not recover towards the transition to the Hawthorn as the seismic transmission does, due to the attenuating nature of the clays to radar. The radar data clearly indicate the location of the water table and transition to the vadose zone.

All the measurements made in the north NAPL area indicated a different structure from the south, specifically the presence of an attenuating zone to seismic transmission from about 3 to $5 \mathrm{~m}$ depth. Seismic transmission was poor, except for one area centered at about $6 \mathrm{~m}$ depth and another between 7.5 and $8 \mathrm{~m}$. Also, because of borehole deviation, surveys could only be made down to about $8 \mathrm{~m}$ depth.

The information obtained in the first year of the project will be utilized in the second year field work. While CPT-rig-installed boreholes have been successful at other sedimentary sites, additional boreholes at the Northeast site should be installed with rotary or sonic drilling to reduce borehole deviation. Seismic and radar crosshole surveys are planned in new, sonic-drilled boreholes in the south NAPL area. The new borehole locations will coincide with those installed in the first-year. Several of them will be core-drilled to obtain core near the CPT-installed boreholes for ground-truth. These boreholes will be 4" diameter, so that a larger, stronger seismic source can be used for transmission through the more attenuating zones. The ability to obtain good quality radar and seismic data at this site provides an opportunity to test the use of multiple geophysical techniques to resolve fluid phase heterogeneities.

The fractured-rock case will also be tested in FY02. At the Idaho National Environmental and Engineering Laboratory, Test Area North (INEEL-TAN) site, time-lapse surveys will be performed to investigate bioremediation-induced changes in the area of the TCE hot-spot. The INEEL-TAN site has known TCE contamination and an unknown remaining DNAPL source zone. Under the EMSP program, we performed 
crosswell seismic surveys of the TAN source-zone, which showed the potential of this technology for fracture-zone characterization (1996-1998). Since this time, bioremediation of TCE by lactate injection has been ongoing. Repeated surveys at this site will provide time-lapse information for bioremediationinduced changes, as well as updated baseline information before the installation of new monitoring wells, planned for FY03. The new monitoring wells will provide a unique opportunity to validate bioremediation of the TAN site, as well as improve on remediation. 


\section{Introduction}

\section{Project Overview}

This report covers the work performed in the first year of a three-year project funded by the USDOE's Subsurface Contaminant Focus Area (SCFA). The objectives of this project are to develop, demonstrate and evaluate, at appropriate field sites, the utility of high frequency seismic imaging methods to detect and characterize non-aqueous phase liquid (NAPL) contamination in sedimentary and fractured rock aquifers. Field tests consist of crosswell seismic tomography acquired before, during and after any remediation action that would potentially affect fluid distributions. Where feasible, other characterization data is obtained, such as crosswell radar, borehole conductivity and cone penetration testing (CPT). Crosswell data are processed to obtain tomographic images, or two-dimensional distributions, of velocity and attenuation. The interpretation of the tomograms utilizes all available site characterization data to relate the geophysical attributes to lithology and fluid phase heterogeneities. Interpretations are validated by evaluation and testing of field cores. Laboratory tests on core retrieved from surveyed locations are performed to determine the relationships between geophysical parameters and solid and fluid phase composition.

In the case of sedimentary aquifers, proof of principle has been demonstrated previously in homogeneous sand-packs at the centimeter and half-meter scale (Geller and Myer, 1995; Geller et al., 2000). The field tests will provide proof-of-principle at the field-scale, by working in an unconsolidated sand aquifer with known presence of NAPL. The ability to upscale from the laboratory to the field is evaluated by conducting field measurements over a range of frequencies that overlap the lowest frequencies used in the laboratory tests. In the fractured rock case, previous field work has shown that fracture zones can be detected by crosswell seismic tomography (Daley et al., 2001; Daley et al., 2000). Laboratory studies have demonstrated that the seismic wave signature is sensitive to the fracture stiffness, and that stiffness is affected by fracture-filling fluids (Pyrak-Nolte and Morris, 2000; Pyrak-Nolte, 1996). The field and laboratory experience provide a physical basis for the potential detection of fractures that would be the important flow paths for NAPL contaminants.

\section{Task Descriptions}

The project is organized within four tasks: A. Field Measurements; B. Laboratory Measurements; C. Data Processing and Interpretation; and D. Planning, Reporting and Reviews. The description of each task follows.

A. Field Measurements: This task covers all planning and performing of geophysical surveys at the host sites. The field sites are selected from sedimentary and fractured rock aquifers known to be contaminated with free-product organics with planned or ongoing remediation activities. Survey planning utilizes available site-characterization information provided by the end-user. Surveys utilize existing boreholes where possible. This task also includes core acquisition from host-sites.

B. Laboratory Measurements: This task includes laboratory measurement of ultrasonic wave propagation through cores from the host-site, with the NAPLs of interest, to determine the sensitivity of the seismic wave signature to the presence of NAPLs, to calibrate the field data and for verification. Electrical properties measurements are also made for sites at which radar surveys are performed. Characterization of solid matrix attributes is performed as indicated by the field data.

C. Data Processing and Interpretation: This task includes processing the field data and seismic attribute tomography (P- and S-wave velocity and attenuation) and difference tomography (as well as for radar, where appropriate). Other methods such as using dispersion analysis will also be investigated. The goal is to identify the most sensitive parameters for detecting NAPLs at the field scale. Data interpretation includes determining the physical properties changes indicated by the difference tomography, identification of NAPL, integration of seismic, radar and other site-characterization data, incorporation of laboratory-measured information and sensitivity analyses. 
D. Planning, reporting and reviews: This subtasks covers development and preparation of Technical Task Plans, annual reports, the Innovative Technology Summary Report, and preparation and participation in the SFCA mid-year, peer and gate reviews.

The remainder of the introduction provides site description and history, and a discussion of the general response of geophysical attributes to physical properties. The remainder of the report is divided into four chapters describing work performed under tasks A, B and C, followed by conclusions.

\section{Site Description and History}

Our field work for FY01 was performed at the Northeast Site of the Pinellas Science, Technology, and Research (STAR) Center, in Largo, Pinellas County, Florida (see Figure 1). The STAR Center is a former DOE facility that manufactured neutron generators and other electronic and mechanical components for nuclear weapons from 1956 to 1994. It is now owned by Pinellas County, with DOE maintaining responsibility for site remediation. The site description, history and characterization are described in the "Northeast Site NAPL Characterization Report," (USDOE, 2000a). The following information is extracted from this report, and an addendum (USDOE, 2000b).

The Northeast Site is located in the northeastern portion of the STAR Center. It is underlain by a surficial aquifer composed of heterogeneous distribution of beach-type deposits, including fine sands with variable shell content, and silty and clayey sands. The water table depth is about $2 \mathrm{~m}$ below ground surface and the aquifer is approximately $9 \mathrm{~m}$ deep. The Hawthorn Group, an 18 to $21 \mathrm{~m}$ thick confining layer, underlies the surficial aquifer. The transition from the surficial deposits to the Hawthorn is gradational. Weathered limestone and clay occur at some areas of the Hawthorn contact. The Hawthorn consists of silty-clay with gravel, silty-sandy phosphatic clay and carbonaceous clay with friable carbonate layers. Below the Hawthorn Group is the Floridian Aquifer, a limestone formation, which is an important regional groundwater resource.

From the late 1950s to the late 1960s, waste and construction debris were disposed in the swampy area of the site. The East Pond (Figure 1) was excavated in 1968 as a borrow pit. In 1986, an expansion of the East Pond was initiated to create additional storm water retention capacity. Excavation activities ceased when contamination was detected directly west of the East Pond.

The Northeast Site was identified as a Solid Waste Management Unit in a Resource Conservation and Recovery Act (RCRA) Facility Assessment conducted by EPA Region IV. Subsequently, a RCRA Facility Investigation was completed and approved in compliance with the facility's Hazardous and Solid Waste Amendments of 1984 permit. Results of site investigations in 1985 and 1987 identified a plume of dissolved volatile organic compounds (VOCs) in the groundwater west of the East Pond. An Interim Corrective Measures (ICM) system, consisting of groundwater recovery wells and onsite treatment, was installed in 1992 (Figure 2). The current treatment system, in operation since July 1997, consists of pumpand-treat with a subsurface hydrogeologic barrier wall at the north end of the site. The pump and treat system includes pre-treatment for iron removal, air stripping and a treated-groundwater holding-tank before discharge to the Pinellas County Publicly Owned Treatment Works.

Per an ICM addendum in 1994, debris was excavated and removed, resulting in an average excavation depth of $4 \mathrm{ft}$, and a maximum depth of 6 feet. Subsequent soil boring logs have noted the presence of debris at greater depths. The removal included a total of 241 drums or drum pieces containing solvent, resin, solidified resin, soil, scrap components and parts and unidentified viscous liquids. Most drums containing liquid were located in the southern area of the site. Sand back-fill was emplaced to restore the site to the original grade.

Three field-scale demonstrations of contaminant remediation technologies were performed under the Innovative Treatment Remediation Demonstrations Program, a joint effort between the DOE, site regulatory agencies and private industry. Membrane separation, an above ground treatment, was performed from July 1995 to March 1996. Dual auger rotary steam stripping was performed in the southern area of 
the site from December 1996 to April 1997, and in situ anaerobic bioremediation was performed in the northern area from February to June 1997.

The area treated by dual auger rotary steam stripping, described in USDOE (1998), is shown in Figure 2. The straight dashed lines indicate the planned area, while the area actually treated is denoted by a camelshaped area. In this process, hot air and steam is injected into the subsurface soil as the drill blades or augers penetrate below the ground surface. The augers shear and mix the soil while the hot air and steam are injected, removing contaminants by the combined processes of stripping, thermal desorption from the soil particles and volatilization. The air, steam and contaminant vapors are carried to the surface by the injected air and steam, and collected for above-ground treatment by a catalytic oxidation system with an acid-gas scrubber (due to the presence of chlorinated hydrocarbons). During operation, the heat of combustion of the contaminants was higher than designed for, which required that the operation reduce its capacity so as not to overheat the catalyst. The greater-than-expected VOC load to the system was attributed to unexpectedly large concentrations of toluene, which has a heat of combustion seven times greater than methylene chloride for which the system was designed. In hind-sight, this is likely to have been caused by the presence of VOCs as non-aqueous phase liquids (NAPLs), which greatly increases the mass of contaminants compared to only aqueous phase contaminants.

The presence of NAPL contaminants was first recognized in April 1998 when an oily substance was observed on sampling devices used in some of the monitoring and recovery wells. In July 1998, sampling indicated very high VOC concentrations at some locations, mainly from the bottom of the wells. In December 1998, approximately 6 gallons of NAPL were recovered from the bottom of recovery well RW06 (see Figure 2). In March 1999, NAPL was recovered from recovery well RW03, but no NAPL was recovered from sampling of RW06. The analysis of the NAPL from RW03 indicated the presence of a suite of volatile and semi-volatile compounds. NAPL samples from both wells were similar in appearance. Approximately 50 to 70 percent (by volume) of the sample consisted of a clear liquid that was determined to be a solvent. Dark brown solids formed approximately 10 to 30 percent of the sample by volume. The solid phase was gelatinous and readily suspended upon agitation. A separate gray, viscous material was also present, and suspected to be clay that was affected by the solvents.

Detailed site characterization was performed in the end of 1999 and the first half of 2000 during a campaign that included almost one hundred soil borings, screening for organics with a photoionization detector and on-site laboratory analysis of the selected samples. Areas of NAPL contamination were identified based on a calculation that accounts for soil absorption and assumes NAPL is present where VOC concentrations are greater than $1 \%$ of the aqueous phase solubility of the neat chemical. Two plumes having both NAPL trichloroethene (TCE) and toluene, and one plume each of methylene chloride and cis1,2-dichloroethene were identified (see Figure 3). This area was extended, as indicated in the figure, to account for uncertainties. NAPL TCE was found at $2 \mathrm{ft}$ and $6 \mathrm{ft}$ into the Hawthorn aquitard at two locations within the southern TCE and toluene plume.

In October 2000, additional NAPL samples were collected from three recovery wells: RW03, RW06 and DRW5. Samples were collected from both the top and bottom of RW03 and RW06, and only from the top of DRW5 because the latter well has no sump. These samples separated into distinct layers, with densities greater than (DNAPL), less than (LNAPL) and equal to that of water (aqueous phase). RW03 had two LNAPL layers and one DNAPL layer, RW06 had one LNAPL and one DNAPL layer, and DRW5 had one LNAPL layer. The samples were analyzed using the following EPA methods: SW846 Methods 8260 plus tentatively identified compounds (TIC) (volatile compounds), 8270 plus TICs (semi-volatile compounds), and 8100 Modified (hydrocarbons). The 8100 analysis of these samples showed that heavy oils comprise 25 to $45 \%$ of the NAPLs. Some samples had boiling temperatures as high as $700^{\circ}$ F. In each sample, the amount of NAPL recovered in boiling point distribution tests ranged from 50 to $70 \%$; the remaining fraction stopped boiling and no more vapor was recovered. A semi-solid material observed in one sample is hypothesized to be an adiprene pre-polymer, based on the fact that a barrel labeled adiprene was found at the site. Six to $45 \%$ of each sample was identified by as mixtures of various hydrocarbons and chlorinated solvents, leaving the remaining fraction of each sample as unknown. 
NAPLs have also been observed in wells RW10, RW11, 0533, M17D, M35D (in the southern NAPL area) and B003 (in the northern NAPL area).

\section{General response of geophysical parameters}

The physical properties that we are focusing on for geophysical NAPL detection in groundwater aquifers and their range of values are summarized in Table 1. The range of these properties for clays and sands overlap, such that no single property value can definitively distinguish between them. These properties are related to seismic $\left(V_{p}\right)$ and $\operatorname{radar}\left(V_{E M}\right)$ velocities through the following equations (e.g. Santamarina, 2001):

$V_{p}=\sqrt{\frac{K+4 / 3 \mu}{\rho}}$,

and

$V_{E M}=\frac{c}{\sqrt{\varepsilon}}$

where $c$ is the electromagnetic wave velocity in free space, $\mu$ is the shear modulus and the other parameters are described in Table 1. The properties are also related to seismic $\left(\alpha_{p}\right)$ and $\operatorname{radar}\left(\alpha_{E M}\right)$ attenuation, approximated by the following equations,

$\alpha_{P} \approx \frac{\pi f}{V_{p} Q}$

where $f$ is frequency of the wave and $Q$ is the quality factor, and

$\alpha_{E M} \approx \frac{b \sigma}{\sqrt{\varepsilon}}$

which applies to a low-loss medium, where $b$ is a constant; other parameters are defined in Table 1 . The inverse of $Q$ is a measure of energy loss per cycle

Equations (3) and (4) account for intrinsic material energy loss, differentiated from apparent amplitude decrease due to scattering (reflection) or spreading. Scattering is a function of the size of a heterogeneity relative to the wavelength, and to the impedance contrast between the scatterer and surrounding media. Seismic impedance is the product of velocity and density. The reflection coefficient $(R)$ of a seismic wave at an interface of two different media is the ratio of the amplitude of the transmitted wave to the incident wave. For a wave that is normal to the direction of propagation, $R$ is a function of the impedance $(z)$ of each medium, 1 and 2 ,

$$
R=\frac{1-\frac{z_{1}}{z_{2}}}{1+\frac{z_{1}}{z_{2}}}
$$




\section{Field Measurements (Task A).}

\section{Field data collection}

LBNL's first field work at Pinellas occurred during the week of May 21, 2001. Four lines of 2" diameter boreholes with blank PVC casing were installed by Fugro Geosciences, Inc. using push technology. The boreholes were pushed with the CPT rod, with the casing behind a sacrificial tip. Once in place, the rod was unscrewed from tip. A CPT lithology log was obtained in one borehole of each line. The log was performed first, then the borehole installed. Two lines of three boreholes each were installed in the south NAPL area (Figure 4), and one line of three boreholes was installed in the north NAPL area (Figure 5). The fourth line consists of two boreholes outside the south NAPL area. The boreholes within each line are spaced in a line approximately 7.5 feet apart. This geometry was designed to provide a measure of true attenuation, by performing surveys between each borehole pair spaced $7.5 \mathrm{ft}$ apart and $15 \mathrm{ft}$ apart. Where possible, the boreholes were located near existing monitoring wells that could potentially be used for surveys. Borehole locations were also set to avoid utilities, locations of previous sample borings, CPT logs and the area of rotary steam stripping. At several locations, there was significant resistance to the CPT, due to the presence of a calcareous lens. In the northern NAPL area, several pushes a few feet apart were attempted before G11 was successfully installed. 
Table 3. Summary of field data acquired the week of May 21, 2001 (borehole pairs are grouped according to lines, see Figures 4 and 5)

\begin{tabular}{|c|c|c|c|c|c|c|c|c|c|}
\hline $\begin{array}{l}\text { borehole } \\
\text { pair }\end{array}$ & $\begin{array}{l}\text { separation } \\
\text { at ground } \\
\text { surface }(\mathrm{m})\end{array}$ & $\begin{array}{l}\text { radar } \\
\text { frequency }\end{array}$ & $\begin{array}{l}\text { Radar tomo } \\
\text { performed? }\end{array}$ & $\begin{array}{l}\text { seismic } \\
\text { acquired? }\end{array}$ & $\begin{array}{l}\text { Seismic } \\
\text { tomo } \\
\text { performed? }\end{array}$ & $\begin{array}{l}\text { CPT } \\
\text { log }\end{array}$ & $\begin{array}{l}\text { Nearby } \\
\text { wells }\end{array}$ & $\begin{array}{l}\text { Nearby SB's } \\
\text { CPT's(9) }\end{array}$ & NAPLs (5) \\
\hline G1-G2 & 2.35 & $100 \mathrm{MHz}$ & yes & yes (8) & yes & G2 & & $\begin{array}{l}\text { CP52, } \\
\text { SB43, S109 }\end{array}$ & $\begin{array}{l}\text { "clean" } \\
\text { (within } \\
\text { NAPL halo) }\end{array}$ \\
\hline G3-G4 & 2.25 & $100 \mathrm{MHz}$ & yes & yes & yes & G4 & $\begin{array}{l}\text { M17D, } \\
\text { RW06 }\end{array}$ & & $\begin{array}{l}\text { TCE, } \\
\text { toluene \& oil }\end{array}$ \\
\hline $\begin{array}{l}\text { G4-G5 } \\
\text { G3-G5 }\end{array}$ & 2.32 & $\begin{array}{l}\text { no data } \\
\text { no data }\end{array}$ & $\begin{array}{l}\text { no data } \\
\text { no data }\end{array}$ & $\begin{array}{l}\text { yes }(7) \\
\text { yes }\end{array}$ & $\begin{array}{l}\text { yes } \\
\text { yes }\end{array}$ & $\begin{array}{l}\text { G4 } \\
\text { G4 }\end{array}$ & & & \\
\hline G6-G7 & 2.23 & $200 \mathrm{MHz}$ & yes & yes & no (2) & G7 & M35D & $\begin{array}{l}\text { SB42, } \\
\text { SB35, CP01 }\end{array}$ & $\begin{array}{l}\text { TCE, } \\
\text { Toluene, } \\
\text { MeCl2 }\end{array}$ \\
\hline G7-G8 & 2.40 & no data & no data & no (1) & no & G7 & & & \\
\hline G9-G10 & 2.17 & $200 \mathrm{MHz}$ & no (4) & Yes (6) & yes & G10 & B003 & CP49, S130 & $\begin{array}{l}\text { TCE, } \\
\text { toluene \& oil }\end{array}$ \\
\hline G10-G11 & 1.42 & no data & no data & no (3) & no & G10 & & & \\
\hline $\begin{array}{l}\text { (1) not dc } \\
\text { (2) only } 4 \\
\text { (3) ran o } \\
\text { (4) only z } \\
\text { (5) accor } \\
\text { (6) a crac } \\
\text { (7) cross } \\
\text { (8) data } \\
\text { (9) SB=s }\end{array}$ & $\begin{array}{l}\text { one after poo } \\
45 \text { travel time } \\
\text { ut of time } \\
\text { zero-offset su } \\
\text { rding to year } \\
\text { ck in the seis } \\
\text {-talk noted d } \\
\text { set had stray } \\
\text { soil boring; }\end{array}$ & $\begin{array}{l}\text { or transmissi } \\
\text { es could be } \\
\text { urvey was pe } \\
2000 \text { site ch } \\
\text { smic source } \\
\text { luring data a } \\
\text { waveforms } \\
P=\text { location o }\end{array}$ & $\begin{array}{l}\text { on in g6-g7 } \\
\text { icked, which y } \\
\text { rformed (not f } \\
\text { aracterization } \\
\text { Nas observed } \\
\text { cquisition } \\
\text { which were ide } \\
\text { f CPT }\end{array}$ & $\begin{array}{l}\text { ll tomograph } \\
\text { USDOE, } 20 \\
\text { ntter this sur } \\
\text { ntified befor }\end{array}$ & $\begin{array}{l}\text { Igh arrival time } \\
\text { hy) } \\
\text { O00b) } \\
\text { vey } \\
\text { e processing }\end{array}$ & to $p$ & orm to & graphy & \\
\hline
\end{tabular}

Table 3 summarizes the data collected during this first week. The CPT-logged borehole in each line is noted. Borehole pairs were surveyed in the order of their numbers. Source and receiver stations were set at $0.125 \mathrm{~m}$ intervals in the borehole. For seismic tomography, the source was placed at a given station in one borehole, while the receiver string with 24 hydrophones was set in the neighboring borehole. The receiver string was moved so that data were collected for all stations in its borehole, and then the source was moved to the next station. The radar system has a single receiver dipole. Due to time constraints, complete crosshole tomographic surveys were not performed in all borehole pairs. Only zero-offset radar data was collected in G7-G8, G9-G10 and G10-G11, which yields average one-dimensional velocity vs. depth inferred between the acquisition borehole pair. Radar transmission was surprisingly good at the site. The amplitudes of the arrivals for the first two borehole pairs surveyed at $100 \mathrm{MHz}$ was so high that the transmitting antenna frequency was increased to $200 \mathrm{MHz}$ at subsequent borehole pairs. Seismic transmission varied significantly within a given borehole pair. The table also indicates the borehole pairs for which tomographic inversion could be performed (discussed under Task C.)

Equipment used for the cross-hole seismic data survey consisted of the following: a rack mounted system containing a computer controlled waveform generator, a high voltage DC power supply, and a high voltage waveform amplifier; a 48 channel digital seismograph; a 24-element hydrophone string; a 1.5" piezoelectric seismic source transducer; assorted cables and batteries. Equipment used for the cross-hole radar data survey consisted of the following: an acquisition computer; a Sensors and Software, Inc. PulseEKKO100 borehole ground penetrating radar system, which includes $30 \mathrm{~m}$ borehole cables and both $100 \mathrm{MHz}$ and $200 \mathrm{MHz}$ borehole antennas. All transmitted radar signals are in the milliwatt range and as such do not fall under FTC regulations or guidelines. 
After the final seismic cross-hole data set was collected between G9-G10, a crack was observed in the seismic source. Such a crack can significantly degrade wave transmission, or cause erratic transmission. The pattern of zero-offset data (discussed under Task C) indicates that transmission was not erratic. Nonetheless, it will require a repeat survey to determine whether or not this crack was present during data collection and affected the data collected, or occurred after the surveys were completed.

Preliminary evaluation of the tomographic data indicated that the boreholes were significantly deviated from vertical orientation. The deviation is attributed to bowing of the CPT rod as it encountered more resistive layers. From August 2-3, 2001, Century Geophysical Corp. of Tulsa, OK performed a magnetic deviation survey in the eleven boreholes installed by LBNL (G1-G11) as well as two exisiting monitoring wells (M17D and 15-B003) installed by rotary drilling. Borehole deviations in wells G8-G11 were so great that the curvature of the borehole prevented the tool (approximately $6 \mathrm{ft}$ long by 1.8 " diameter) from reaching the bottom of the well. The general procedure of the survey involves lowering the deviation tool to the bottom of each well (or to the deepest possible depth) and slowly logging the well as the tool is brought upward toward the surface. The tool is comprised of a magnetic compass whose signal is converted to an electric signal, which is then transmitted through the wireline and encoded/deciphered on a computer system at the surface. The accuracy is traditionally believed to be less than a centimeter in the $\mathrm{x}$ $\mathrm{y}-\mathrm{z}$ directions.

The CPT-installed boreholes were significantly deviated. Borehole G4 deviated by four feet over 30 feet depth. For such large deviations, the accuracy of the deviation survey is critical in making geometric corrections for tomography. The monitoring wells were not deviated. During the same visit, conductivity logs were taken in the eleven CPT boreholes, using a Geonics, Corp. EM-39 electrical conductivity logger. It operates as an induction logger by setting up a current in the formation and measuring the induced current, which is then converted to a conductivity value.

The borehole locations, and ground and top of casing elevations were surveyed by Harry W. Marlow, Inc., on August 7, 2001, shown in Table 4. The surveyed locations of the boreholes are shown in Figures $5 \& 6$. Borehole G6 is located on the boundary of the rotary steam stripping area.

Table 4. Surveyed locations and elevations of LBNL boreholes (in feet)

\begin{tabular}{|c|c|c|c|c|}
\hline DESCRIPTION & NORTHING & EASTING & TOP OF CASING & GROUND \\
\hline LBNL G1 & 1288404.9 & 258512.8 & 18.18 & 17.6 \\
\hline LBNL G2 & 1288399.3 & 258518.1 & 18.45 & 17.9 \\
\hline LBNL G3 & 1288403.1 & 258481.6 & 18.50 & 17.6 \\
\hline LBNL G4 & 1288408.2 & 258486.9 & 18.19 & 17.7 \\
\hline LBNL G5 & 1288413.6 & 258492.2 & 17.80 & 17.6 \\
\hline LBNL G6 & 1288445.2 & 258506.3 & 18.48 & 17.8 \\
\hline LBNL G7 & 1288449.1 & 258512.5 & 18.45 & 17.9 \\
\hline LBNL G8 & 1288452.9 & 258519.4 & 18.62 & 17.9 \\
\hline LBNL G9 & 1288686.6 & 258587.2 & 18.12 & 17.4 \\
\hline LBNLG10 & 1288689.3 & 258593.8 & 17.86 & 17.4 \\
\hline LBNLG11 & 1288691.2 & 258598.0 & 18.08 & 17.3 \\
\hline
\end{tabular}

A third field trip was planned for FY01 to core-drill near the borehole lines, and perform additional surveys. However, other site activities precluded a visit during the month of September, and so this work has been postponed to FY02. 
Small grab samples that were left-over from the year 2000 sampling and analysis activities (described in the previous section) were sent to us in the beginning of FY01. Samples were obtained with hollow stem auger drilling and split barrel sampling and stored in $60 \mathrm{~mL}$ jars. The samples included a 3" diameter $\mathrm{x}$ 4.5" inch long core sample from the Hawthorn unit, labeled 12-0528. Table 5 shows the samples obtained, their depths, and reported VOC concentrations (USDOE 2000a). Hydrocarbon analysis was not performed on these samples. Sample locations are shown in Figure 6.

Table 5. Grab samples obtained from Pinellas Northeast Site

\begin{tabular}{|c|c|c|c|c|c|}
\hline $\begin{array}{l}\text { Sample } \\
\text { ID }\end{array}$ & $\begin{array}{l}\text { Depth } \\
\text { (ft } \\
\text { bgs) }\end{array}$ & $\begin{array}{l}\text { Description from borehole } \\
\text { summary, USDOE (2000a) } \\
\text { (depth for which the } \\
\text { description was made is } \\
\text { indicated in parentheses) }\end{array}$ & $\begin{array}{l}\operatorname{VOCs}^{(1)}(\mu \mathrm{g} / \mathrm{kg}) \\
(\mathrm{USDOE}, 2000 \mathrm{a})\end{array}$ & $\begin{array}{l}\text { VOCs }> \\
\text { NAPL cut- } \\
\text { off }{ }^{(2)} \\
\text { (USDOE, } \\
\text { 2000a) }\end{array}$ & $\begin{array}{l}\text { Total } \\
\text { VOCs } \\
(\mu \mathrm{g} / \mathrm{kg})\end{array}$ \\
\hline SB42-01 & 2.5 & $\begin{array}{l}\text { Surficial sand and shell deposits, } \\
\text { dry, brown }\left(0-4^{\prime}\right)\end{array}$ & n.d. & & n.d. \\
\hline SB42-02 & 4.0 & & n.d. & & n.d. \\
\hline SB42-03 & 7.0 & $\begin{array}{l}\text { Sand very poorly sorted with } \\
\text { shells, wood and brick debris, } \\
\text { moist }(6.0)\end{array}$ & $\begin{array}{l}\text { Tol=270; } \\
\text { m\&p-Xyl=480; } \\
\text { o-Xyl }=160\end{array}$ & & 910 \\
\hline SB42-04 & 9.0 & & $\mathrm{TCE}=140$ & & 140 \\
\hline SB42-05 & 11.5 & $\begin{array}{l}\text { Sand well sorted, wet, loose, } \\
\text { black oily sheen (rainbow) sand } \\
\text { fine to very fine (11.5) }\end{array}$ & $\begin{array}{l}\text { Ben=56; } \\
\text { Tol=1100;EtBen=67; } \\
\text { m\&p-Xyl=160; o-Xyl=71 }\end{array}$ & & 1,454 \\
\hline SB42-06 & 14.0 & $\begin{array}{l}\text { Color becomes mottled brown to } \\
\text { black (13.5) }\end{array}$ & $\begin{array}{l}\mathrm{c}-1,2- \\
\mathrm{DCE}=25000 ; \mathrm{Tol}=15000\end{array}$ & Tol & 40,000 \\
\hline SB42-07 & 16.0 & & $\begin{array}{l}\text { VC }=960 ; \mathrm{c}-1,2- \\
\mathrm{DCE}=14000 ; 1,1,1- \\
\text { TCA }=870 ; \text { Tol }=16000\end{array}$ & Tol & 31,830 \\
\hline SB42-08 & 16.0 & & $\begin{array}{l}\mathrm{VC}=1200 ; \mathrm{c}-1,2- \\
\mathrm{DCE}=11000 ; \mathrm{TCE}=1300 ; \\
\text { Tol }=16000\end{array}$ & Tol & 29,500 \\
\hline SB42-09 & 19.0 & $\begin{array}{l}\text { Color becomes gray with black } \\
\text { staining (19.8) }\end{array}$ & $\begin{array}{l}\mathrm{VC}=1800 ; 1,1,1- \\
\mathrm{TCA}=5600 ; \mathrm{Tol}=9700\end{array}$ & & 17,100 \\
\hline SB42-10 & 21.3 & & $\begin{array}{l}\mathrm{MeCl} 2=290,000 ; \mathrm{c}-1,2- \\
\mathrm{DCE}=12000 ; \mathrm{TCE}=58000 ; \\
\text { Tol=18000 }\end{array}$ & $\begin{array}{r}\mathrm{MeCl} 2 \\
\text { TCE, Tol }\end{array}$ & 378,000 \\
\hline SB42-11 & 24.0 & & $\begin{array}{l}\mathrm{VC}=7700 ; \mathrm{MeCl} 2=22,000 ; \\
\mathrm{c}-1,2- \\
\mathrm{DCE}=570 ; \mathrm{TCE}=1200 ; \mathrm{Tol} \\
=4300\end{array}$ & & 40,900 \\
\hline SB42-12 & 25.0 & & $\begin{array}{l}\mathrm{VC}=7700 ; \mathrm{MeCl}=14000 ; \\
\mathrm{c}-1,2- \\
\mathrm{DCE}=3300 ; \mathrm{TCE}=4500 ; \mathrm{T} \\
\mathrm{ol}=4800\end{array}$ & & 27,370 \\
\hline SB42-13 & 27.5 & $\begin{array}{l}\text { Clayey sand poorly sorted } \mathrm{w} / \\
\text { shells and phosphate nodules to } \\
40 \% \text {, dark brown, wet, loose, } \\
\text { sand is fine to very fine }(26.3)\end{array}$ & $\begin{array}{l}\mathrm{MeCl} 2=290,000 ; \mathrm{c}-1,2- \\
\mathrm{DCE}=34000 ; \mathrm{TCE}=47000 ; \\
\text { Tol }=18000\end{array}$ & $\begin{array}{r}\mathrm{MeCl} 2, \\
\mathrm{TCE}, \mathrm{Tol}\end{array}$ & 389,000 \\
\hline SB42-14 & 28.5 & & $\begin{array}{l}\mathrm{MeCl} 2=36000 ; \mathrm{c}-1,2- \\
\mathrm{DCE}=5700 ; \mathrm{TCE}=8400 ; \mathrm{T} \\
\mathrm{ol}=9800\end{array}$ & & 59,900 \\
\hline
\end{tabular}


Table 5. Grab samples obtained from Pinellas Northeast Site (cont'd)

\begin{tabular}{|c|c|c|c|c|c|}
\hline $\begin{array}{l}\text { Sample } \\
\text { ID }\end{array}$ & $\begin{array}{l}\text { Depth } \\
\text { (ft } \\
\text { bgs) }\end{array}$ & $\begin{array}{l}\text { Description from borehole } \\
\text { summary, USDOE (2000a) } \\
\text { (depth for which the } \\
\text { description was made is } \\
\text { indicated in parentheses) }\end{array}$ & $\begin{array}{l}\operatorname{VOCs}^{(1)}(\mu \mathrm{g} / \mathrm{kg}) \\
(\text { USDOE, 2000a) }\end{array}$ & $\begin{array}{l}\text { VOCs }> \\
\text { NAPL cut- } \\
\text { off }^{(2)} \\
\text { (USDOE, } \\
\text { 2000a) }\end{array}$ & $\begin{array}{l}\text { Total } \\
\text { VOCs } \\
(\mu \mathrm{g} / \mathrm{kg})\end{array}$ \\
\hline SB48-01 & 2 & Surficial sand and shell & $\mathrm{c}-1,2-\mathrm{DCE}=57$ & & 57 \\
\hline SB48-02 & 5.5 & $\begin{array}{l}\text { Fine to very fine sand, well } \\
\text { sorted, moist. Brown with } \\
\text { vertical zones of black staining } \\
(3.5)\end{array}$ & n.d. & & n.d. \\
\hline SB48-03 & 7.6 & Wet $(7.5)$ & $\mathrm{VC}=63 ; \mathrm{c}-1,2-\mathrm{DCE}=80$ & & 143 \\
\hline SB48-04 & 6.7 & & $\mathrm{c}-1,2-\mathrm{DCE}=62$ & & 62 \\
\hline SB48-05 & 9.8 & & $\mathrm{VC}=80$ & & 80 \\
\hline SB48-06 & 11.8 & & $\mathrm{VC}=220$ & & 220 \\
\hline SB48-07 & 14.0 & Color becomes gray (13.7) & $\mathrm{VC}=140$ & & 140 \\
\hline SB48-08 & 16.0 & $\begin{array}{l}\text { Color black with oily rainbow } \\
\text { sheen }(15.8)\end{array}$ & n.d. & & n.d. \\
\hline SB48-09 & 17.0 & & $\begin{array}{l}\mathrm{VC}=5900 ; \mathrm{c}-1,2- \\
\mathrm{DCE}=45000 ; \text { Tol }=3000\end{array}$ & & 53,900 \\
\hline SB48-10 & 19.6 & $\begin{array}{l}\text { Color mottled tan/brown/black } \\
(18.4)\end{array}$ & $\begin{array}{l}\mathrm{VC}=4200 ; \mathrm{c}-1,2- \\
\mathrm{DCE}=58000 ; \text { Tol-3100 }\end{array}$ & & 65,300 \\
\hline SB48-11 & 21.6 & & $\begin{array}{l}\mathrm{VC}=5000 ; \mathrm{c}-1,2- \\
\mathrm{DCE}=71000 ; \text { Tol }=3800\end{array}$ & $\mathrm{DCE}$ & 79,800 \\
\hline SB48-12 & 23.6 & & $\begin{array}{l}\mathrm{VC}=9600 ; \mathrm{c}-1,2- \\
\mathrm{DCE}=78000 ; \text { Tol }=4300\end{array}$ & & 91,900 \\
\hline SB48-13 & 25.6 & Color gray (25.2) & $\begin{array}{l}\mathrm{VC}=18000 ; \mathrm{c}-1,2- \\
\mathrm{DCE}=110000 ; \mathrm{Tol}=5500\end{array}$ & DCE & 133500 \\
\hline SB48-14 & 28.0 & $\begin{array}{l}\text { Sandy clay very poorly sorted, } \\
\text { light gray small shell fragments } \\
\text { and phosphate nodules to } 20 \% \\
(27.8)\end{array}$ & $\begin{array}{l}\mathrm{VC}=15000 ; \mathrm{c}-1,2- \\
\mathrm{DCE}=110,000 ; \mathrm{Tol}=46,00 \\
0\end{array}$ & DCE, Tol & 129,600 \\
\hline SB48-15 & 29.7 & & $\begin{array}{l}\mathrm{VC}=6100 ; \mathrm{c}-1,2- \\
\mathrm{DCE}==44000\end{array}$ & & 50,100 \\
\hline SB59-02 & 24.0 & $\begin{array}{l}\text { Sandy clay, poorly sorted, shells } \\
\text { and phosphate nodules to } 30 \% \text {, } \\
\text { gray }(24.3)\end{array}$ & $\mathrm{VC}=270 ;$ Tol $=270$ & & 540 \\
\hline SB59-03 & 26.0 & & $\begin{array}{l}\mathrm{VC}=1600 ; \mathrm{c}-1,2- \\
\mathrm{DCE}=3200 ; \text { Tol }=280\end{array}$ & & 5,080 \\
\hline SB59-04 & 28.0 & & $\begin{array}{l}\mathrm{VC}=1700 ; \mathrm{c}-1,2- \\
\mathrm{DCE}=16000 ; \text { Tol }=1800\end{array}$ & & 19,500 \\
\hline SB59-05 & 29.7 & $\begin{array}{l}\text { Phosphate gravels (to } 1.5 \% \text {, with } \\
\text { shells and limestone, } 10 \% \text { clay } \\
(29.7)\end{array}$ & $\begin{array}{l}\mathrm{MeCl} 2=5500 ; \mathrm{c}-1,2- \\
\mathrm{DCE}=38000 ; \mathrm{TCE}=15000 \\
0 ; \mathrm{Tol}=34000\end{array}$ & Tol & 227,500 \\
\hline
\end{tabular}

Notes for Table 5 .

(1) n.d.=not detected; $\mathrm{VC}=$ vinyl chloride; c-1,2-DCE= c-1,2-dichloroethene; $\mathrm{MeCl}$ =methylene chloride; Ben=benzene; Tol=toluene; EtBen=ethylbenzene; $m \& p-X y l=m \& p-x y l e n e ; o-X y l=0-x y l e n e$

(2) NAPL cut-off values: $\mathrm{TCE}=20,4000 \mu \mathrm{g} / \mathrm{kg} ; \mathrm{c}-1,2-\mathrm{DCE}=71,000 \mu \mathrm{g} / \mathrm{kg} ; \mathrm{MeCl} 2=227,000 \mu \mathrm{g} / \mathrm{kg} ; \mathrm{Tol}=15,000$ $\mu \mathrm{g} / \mathrm{kg}$. 


\section{Laboratory Measurements (Task B)}

The purpose of the laboratory measurements is to obtain relevant soil and liquid properties that will support the interpretation of the geophysical measurements performed at the selected field sites. The lab measurements also provide relationships between geophysical attributes and sample properties that are used in numerical sensitivity studies. In FY01, this effort was directed towards designing and assembling the measurement test cells for the specific conditions of the Pinellas site samples and developing analytical procedures. These specific conditions include the presence of fine-grained materials with variable saturations of water and NAPL. The fine-grained materials include fine sands, silty-sands, clayey sands and sandy-silty clays, based on the inspection of the grab samples from the site (described in the previous section). Some of the NAPLs that need to be tested are aggressive solvents, including TCE, toluene and methylene chloride.

\section{P-wave transmission}

A triaxial test-cell was designed and built to measure P-wave transmission through soil samples of varying NAPL/water saturation, shown in Figure 7, by pulse-transmission. The endcaps are 2.87" O.D and made of compression molded polyphenylene sulfide, also known as PPS or ryton, which is resistant to organic solvents. A well in each endcap holds the transducer and isolates it from direct contact with the sample. The transducers are $0.5 \mathrm{MHz}$ P-wave contact transducers with a 1" diameter element (Part No. V101, Panametrics, Waltham, MA). Each endcap has two fluid ports that run through the annulus through the length of the endcap. The face of the endcap annulus has flow distribution grooves. A 400-mesh stainless steel screen (0.001" wire diameter) covers the endcap face for further flow distribution. A porous ceramic plate with a 2 bar entry pressure can be placed on the endcap on the down-gradient side of the sample to prevent the NAPL that has been injected into the sample from flowing out, as long as liquid pressures are less than 2 bars.

The sample is held by a flexible wall jacket, either teflon heat-shrink tube for pure liquids and coarsegrained samples, or an elastomer jacket for finer-grained samples. The only elastomer found to be compatible with TCE is pure viton, which must be custom fabricated. Ready-made elastomer jackets such as viton-coated nitrile and chloroprene reacted with TCE.

The sample axial and confining loads are maintained by Isco syringe pumps that operate in constant pressure mode (Figure 8). Liquid volume changes in the confining liquid are monitored from the pump display. To represent shallow subsurface conditions, the confining pressure is set to 0.6 times the axial pressure. Changes in sample length are monitored by manually recording the reading from a deformation gage attached to the load frame and resting on the top of the upper endcap.

The transducer is driven by a voltage pulse generator (IRCO, model M1k-20) set to produce an approximate square wave of about $0.8 \mu$ s width and 400 volts amplitude. One hundred received waveforms are stacked and saved on a digital oscilloscope (Lecroy 9310A, $400 \mathrm{MHz}$ ).

P-wave velocities for various fluids and solids are shown in Table 6. The velocities have either been taken from the literature, or measured in our lab. NAPLs and air have significant velocity contrasts with water. The fraction of energy of an incident P-wave reflected by a flat phase interface is computed from the difference in the acoustic impedance of each phase. There is a range of values for different NAPL-water pairs. Lab measurements to-date suggest that scattering of transmitted waves will be more significant for the NAPL-water pairs that have higher reflection coefficients. The table shows that the impedance contrast between water-saturated sand and PPS is lower than for any other sand-solid pairs, making PPS a good choice for endcap material. 
Table 6. P-wave transmission through various fluids and solids.

\begin{tabular}{|c|c|c|c|c|c|}
\hline & $\begin{array}{l}\text { acoustic } \\
\text { velocity } \\
\text { Vp } \\
(\mathrm{km} / \mathrm{s})\end{array}$ & $\begin{array}{c}\text { density } \rho \\
(\mathrm{kg} / \mathrm{m} 3)\end{array}$ & \begin{tabular}{|c|} 
acoustic \\
impedance $\rho V_{p}$ \\
$\left(\mathrm{~kg} / \mathrm{m}^{2}-\mathrm{s}\right)$
\end{tabular} & $\begin{array}{l}\text { bulk modulus } \\
V_{p}^{2} \rho(\mathrm{MPa})\end{array}$ & $\begin{array}{c}\text { reflection } \\
\text { coefficient } R\end{array}$ \\
\hline Fluids & & & & & $\begin{array}{r}\text { from water to } \\
\text { NAPL }\end{array}$ \\
\hline Air & $0.344^{(2}$ & 1.293 & $4.447 \mathrm{E}+02$ & 0.153 & $9.99 \mathrm{E}-01$ \\
\hline water & $1.47^{(2)}$ & 997 & $1.493 \mathrm{E}+06$ & 2234 & - \\
\hline n-dodecane & $1.290^{(3)}$ & 745 & $9.611 \mathrm{E}+05$ & 1240 & $2.17 \mathrm{E}-01$ \\
\hline gasoline & $1.25^{(2)}$ & 730 & $9.125 \mathrm{E}+05$ & 1141 & $2.41 \mathrm{E}-01$ \\
\hline toluene & $1.321^{(3)}$ & 870 & $1.149 \mathrm{E}+06$ & 1518 & $1.30 \mathrm{E}-01$ \\
\hline isooctane & $1.120^{(3)}$ & 690 & $7.728 \mathrm{E}+05$ & 866 & $3.18 \mathrm{E}-01$ \\
\hline RTV & $1.000^{(3)}$ & 1080 & $1.080 \mathrm{E}+06$ & 1080 & $1.60 \mathrm{E}-01$ \\
\hline $\begin{array}{l}\text { methylene chloride } \\
\left(\mathrm{CH}_{2} \mathrm{Cl}_{2}\right)\end{array}$ & $1.080^{(3)}$ & 1335 & $1.442 \mathrm{E}+06$ & 1557 & $1.74 \mathrm{E}-02$ \\
\hline tetrachloroethene & $1.080^{(3)}$ & 1631 & $1.761 \mathrm{E}+06$ & 1902 & $-8.27 \mathrm{E}-02$ \\
\hline Carbon tetrachloride & $0.926^{(3)}$ & 1584 & $1.467 \mathrm{E}+06$ & 1358 & $8.69 \mathrm{E}-03$ \\
\hline$\overline{T C E}$ & $1.05^{(3)}$ & 1480 & $1.554 \mathrm{E}+06$ & 1632 & $-2.02 \mathrm{E}-02$ \\
\hline freon 113 & $0.716^{(2)}$ & 1560 & $1.117 \mathrm{E}+06$ & 800 & $1.44 \mathrm{E}-01$ \\
\hline Solids & & & & & $\begin{array}{l}\text { from water- } \\
\text { saturated sand to } \\
\text { solid }\end{array}$ \\
\hline $\begin{array}{l}\text { sand-water sat'd } \\
\text { lonestar } 2 / 12\end{array}$ & $1.864^{(3)}$ & 2010 & $3.747 \mathrm{E}+06$ & 6984 & \\
\hline lexan & $2.238^{(3)}$ & 1180 & $2.641 \mathrm{E}+06$ & 5910 & $1.73 \mathrm{E}-01$ \\
\hline pps & $2.519^{(3)}$ & 1329 & $3.347 \mathrm{E}+06$ & 8431 & $5.64 \mathrm{E}-02$ \\
\hline teflon & $1.345^{(3)}$ & 2187 & $2.941 \mathrm{E}+06$ & 3956 & $1.20 \mathrm{E}-01$ \\
\hline aluminum & $6.420^{(2)}$ & 2700 & $1.733 \mathrm{E}+07$ & 111284 & $-6.45 \mathrm{E}-01$ \\
\hline \multicolumn{6}{|c|}{$\begin{array}{l}\text { (1) a negative number indicates the polarization of the wave changes; see Equation (5) } \\
\text { (2) ref: http://www.ultrasonic.com/tables } \\
\text { (3) measured in our lab } \\
\text { References for other data are available upon request. }\end{array}$} \\
\hline
\end{tabular}

To obtain adequate sample volume for testing, several of the air-dried grab samples having similar appearance (color, grain size distribution) were combined. Samples SB48-9, SB48-10 and SB48-11 were combined, and the composite sample renamed SB48-9,10,11. This sample was packed into the test cell by holding the flexible membrane (viton-coated nitrile) in a membrane-stretcher, placing it over the bottom endcap and pouring the sample into the assembly. The top endcap was placed over the sample and the membrane was stretched over both endcaps. The sample was placed under vacuum to provide confining pressure, and the membrane stretcher was removed. The rest of the triaxial cell was assembled (confining cell wall, top flange) and an axial load was applied. The confining cell was filled with deionized distilled water and the vacuum was reduced as the confining pressure was increased. Once the vacuum was relieved, the axial and confining loads were set to their final values of 2.86 and 1.72 bars, respectively. The sample was flushed with $\mathrm{CO}_{2}$ for thirty minutes before injecting deaired water. The water was deionized, distilled water that had been mixed with soil to chemically equilibrate it with the sample and then decanted. This soil water was then degassed under vacuum. 
Figure 9 shows the change in P-waves through the sample as the first pore volume of water is injected. As water is injected, the amplitude decreases and the arrival time increases. The period of the wave also increases. After one pore volume is injected, there is still a lot of residual air in the sample, which results in a strongly attenuated wave. As more pore volumes of water flow through the sample, shown in Figure 10, an earlier, higher frequency arrival appears. With increasing pore volumes of flow, more residual air is dissolved, and the amplitude of the early arrival increases and the travel time decreases. Between the time 9.5 and 40 pore volumes of water had passed through the sample, the amplitude of the P-wave increased by a factor of about 200. Once saturated, the waveform does not change as increasing pore volumes of water are pumped through.

The initial height of the dry sample under load was $37.5 \mathrm{~mm}$, and decreased to $36.2 \mathrm{~mm}$ after final watersaturation. The sample wall outside diameter was approximately $4 \mathrm{~mm}$ smaller than the outside diameter of the endcaps, but this couldn't be measured precisely. The porosity at final water saturation is estimated to be 0.48 , based on the measured sample height, assumed values for sample diameter $(68.9 \mathrm{~mm})$ and specific gravity of the soil (2.65). At $36.2 \mathrm{~mm}$ sample height, this gives a sample pore volume of $64 \mathrm{~mL}$.

Once the sample was water-saturated, liquid TCE was injected at a constant flow rate of $1 \mathrm{~mL} / \mathrm{min}$ into one of the bottom fluid ports. The TCE was dyed with $125 \mathrm{mg} / \mathrm{L}$ oil-red-O dye (Sigma Aldrich). The TCE injection pressure was approximately 0.1 bar. Effluent flowed to a $100 \mathrm{~mL}$ graduated cylinder sealed with a stopper connected to a granulated carbon trap to prevent the escape of TCE vapors into the room. The Pwave transmission was monitored as the TCE was injected and waveforms were obtained for every 5 to 10 $\mathrm{mL}$ of injected liquid. TCE was observed in the effluent line after $17 \mathrm{~mL}$ of TCE had been injected. After $25 \mathrm{~mL}$ of injected TCE, the sample jacket began to buckle due to reaction with the TCE. However, there was no leakage of confining water into the sample (determined from monitoring the liquid volume in the confining pressure pump), nor did the sample height change at this time. When water was no longer displaced from the sample, the TCE injection rate was increased to a maximum of $14 \mathrm{~mL} / \mathrm{min}$ and injection pressure of 0.15 bar. Following this, water was injected from the bottom sample port, until it became apparent from the confining pressure pump that confining water was leaking into the sample.

The waveforms during TCE injection are shown in Figure 11. The volume of TCE injected is estimated from the amount of TCE pumped into the sample, and the amount of TCE and water in the effluent cylinder. This volume also accounts for TCE in the fluid ports and tubing, however an unknown volume of TCE was contained in the buckled sample jacket. As the injected volume of TCE increases, the travel time is delayed and the amplitude decreases, while the general shape of the waveforms remain constant, with no apparent change in frequency. Figure 12 shows the change in P-wave velocity and amplitude, as measured from trough to peak of the first arrival, for the entire experiment. Velocities decrease as TCE is injected, except for two points immediately following the observation of the sample jacket swelling (denoted in the figure). At the same time, the amplitudes fall off their generally decreasing trend. Once water is injected, velocities and amplitudes recover towards their water-saturated values. The decreases in velocity and amplitude with small changes in TCE volume indicate TCE redistribution within the sample. Assuming a pore volume of $64 \mathrm{~mL}$ (for the porosity and sample dimensions noted previously), the maximum fraction of TCE in the pore space is 0.48 , and the final saturation of TCE once the jacket appeared to break was 0.20 . The percent change in velocity at these two endpoints was 7.6 and $4.3 \%$, respectively.

The change in amplitude is smaller than has been observed for other NAPL-water pairs in coarser sands. This may be due to the lower reflectivity between TCE and water compared to other water-NAPL pairs that have been tested. Reflection coefficients for NAPL-water pairs are shown in Table 6. For larger reflection coefficients, more energy is lost from the propagating wave as it is scattered at NAPL-water interfaces. Another factor may be the fine-grained nature of the sample, relative to previous tests, which presented greater flow resistance to the NAPL and caused a larger fraction to by pass the sample and migrate along the sample walls as the viton-coated latex jacket swelled. Tests will be performed with other NAPL-water pairs that have larger reflection coefficients, specifically toluene-water, to test the hypothesis of the role of reflection coefficients on P-wave transmission.

Future tests will be performed with custom-fabricated viton jackets that are non-reactive to TCE, methylene chloride and toluene and should prevent the injected liquid from bypassing the sample. P-wave 
transmission will also be measured through the finer-grained sample SB48-14,15. We plan to obtain minimally disturbed core from the site for testing in FY02.

\section{Electrical Properties}

Based on the success of radar transmission at the Pinellas site, we decided to perform electrical properties measurements in the laboratory. The dielectric permittivity is measured by means of time domain reflectometry, using the Trase System I, 6050X1, with a mini-buriable probe, model 6111. The probe consists of three metal rods that are $8 \mathrm{~cm}$ long and spaced to an outside width of $2.8 \mathrm{~cm}$. The probes are connected to a base that is $1 \mathrm{~cm} \times 4 \mathrm{~cm}$ in area. A lucite sample box with inside dimensions of $4 \mathrm{~cm} \mathrm{x} 2 \mathrm{~cm}$ x $15 \mathrm{~cm}$ tall was built to minimize sample volume and end effects on the measurement. The height of the box allows for sample consolidation before TDR measurement. Samples are mixed with deionized, distilled water that has been deaired, and are then loaded under constant axial pressure of 1.75 bars. Water drainage occurs through the top plug of the sample and through strips of filter membrane (Gellman-Pall Versapore, $0.45 \mu \mathrm{m}$ opening) that run the full depth along the $2 \mathrm{~cm}$ wide sides of the box. Sample SB4814,15 was tested for consolidation. Over several days it consolidated to $87 \%$ of its original height. These measurements will continue in FY02.

\section{Sample Characterization}

Two soil samples were sieved to obtain their particle size distribution. The results for SB48-9,10,11 and SB48-14,15 are shown in Figure 13. The values of $d_{60}$ for both sands are very close, precisely $172 \mu \mathrm{m}$ for SB48-9,10,11, and slightly less for SB48-14,15. However SB48-14,15 has about 15\% fines (grain diameters less than $75 \mu \mathrm{m}$ ) compared to only $5 \%$ for SB48-9,10,11. The larger fraction of fines has a significant effect on permeability. NAPL injection pressures into water-saturated SB48-14,15 are likely to be quite high.

The fine fraction of selected grab samples was analyzed. The physical attributes of the bulk sample, clay fraction and coarser fraction, as well as the color of the supernatant after water was mixed with the sample are noted in Table 7. XRD analysis was performed on air-dried, and glycolated, oriented clay fraction $(<2$ $\mu \mathrm{m})$. Mineralogical identification was based on the qualitative evaluation of the relative main peak strengths, and are summarized in Table 8. The main mineralogical differences concern the relative fractions of kaolinite vs. smectite. The Hawthorn sample is all smectite and smectite/chlorite. Sample SB48-05 has equivalent peak strengths for both kaolinite and smectite. All the other samples have strong peaks for kaolinite, and trace peaks for smectite. 
Table 7. Physical attributes of selected grab samples.

\begin{tabular}{|c|c|c|c|c|}
\hline \multirow[t]{2}{*}{ Sample ID } & \multirow{2}{*}{$\begin{array}{l}\text { Lithologic description of bulk } \\
\text { sample }\end{array}$} & \multicolumn{3}{|c|}{ Color } \\
\hline & & $\begin{array}{l}\text { Clay } \\
\text { fraction }\end{array}$ & Coarser fraction & Super-natant \\
\hline SB42-11 (24.0’) & gray fine sand & dark brown & buff sand & brown \\
\hline SB48-05 (9.8') & $\begin{array}{l}\text { *wet, white sand w/rock frag's } \\
\text { and abund. shell frag's }\end{array}$ & gray-brown & $\begin{array}{l}\text { clean white sand } \\
\text { and shell } \\
\text { fragments }\end{array}$ & brown \\
\hline $\begin{array}{l}\text { SB48-9,10,11 } \\
\left(17^{\prime}, 19.6 '\right. \\
\left.21.6^{\prime}\right)\end{array}$ & black powder $(<270 \mathrm{mesh})$ & dark brown & buff sand & black \\
\hline SB48-12 (23.6') & $\begin{array}{l}\text { brown fine sand w/darker } \\
\text { fines }\end{array}$ & dark brown & clean white sand & dark brown \\
\hline $\begin{array}{l}\text { SB48-14,15 } \\
\left(28.0^{\prime}, 29.77^{\prime}\right)\end{array}$ & $\begin{array}{l}\text { *buff fine sand and silt, } \\
\text { w/coarse sand \& pebbles }\end{array}$ & gray & $\begin{array}{l}\text { buff sand, w/fine } \\
\text { black grains }\end{array}$ & brown \\
\hline $12-0528\left(40^{\prime}\right)$ & $\begin{array}{l}\text { Hawthorn - dark grey intact } \\
\text { gummy lump,nearly hardened; } \\
\text { resuspended }\end{array}$ & light brown & $\begin{array}{l}\text { buff sand, } \\
\text { w/black grains }\end{array}$ & brown \\
\hline \multicolumn{5}{|c|}{$\begin{array}{l}\text { *strong reaction to dilute HCL (pertains to sand in SB48-15,14, but only to shell component in SB48- } \\
\text { 05); other samples show no reaction. }\end{array}$} \\
\hline
\end{tabular}

Table 8. Mineralogy of clay fraction of selected samples

\begin{tabular}{|l|l|l|l|}
\hline Sample ID & Kaolinite & Smectite* & comments \\
\hline SB42-11 & strong & trace & \\
\hline SB48-05 & strong & strong & smectite equal to or stronger than kaolinite \\
\hline SB48-9,10,11 & strong & trace & \\
\hline SB48-12 & strong & trace & \\
\hline SB48-14,15 & strong & trace & \\
\hline $12-528$ & $\sim$ none & strong & smectite and/or mixed-layer smect/chlorite \\
\hline *smectite is used here to denote generalized expandable clay, without regard to composition. \\
\hline
\end{tabular}

\section{Data Processing and Interpretation (Task C)}

\section{Borehole characterization}

The summary of the CPT logs and lithology of the boreholes installed in May 2001 is shown in Figure 14. The graphs show the measured tip, sleeve and piezo pressure and the friction ratio, calculated from the ratio of sleeve to tip pressure. The soil stratigraphy was identified by the CPT contractor, using Campanella and Robertson's Simplified Soil Behavior Chart (Robertson and Campanella, 1983) based on tip pressure and the friction ratio. This lithology has not been calibrated to the site. Coring near the locations of CPT logs in FY02 may provide an opportunity for calibration. The piezo pressure increases with depth as hydrostatic pressures increase, then decreases sharply at soil texture changes that are flow barriers. The three lithologies in the southern NAPL area (G2, G4 and G7) are similar, with the upper $7 \mathrm{~m}$ (measured from top of casing, TOC) consisting of sands with some silty-sand layers. The CPT logs show changes within the layers identified as sands, which suggests that these are not homogeneous units. The silty sand layers appear at almost the same elevations at each location. The transition to the Hawthorn Group begins at around 7.5 to $8 \mathrm{~m}$ below TOC. In the northern NAPL area, the CPT lithology for G10 shows clayey layers within the upper $11 \mathrm{~m}$ of sand, just above 4 and $9 \mathrm{~m}$ below TOC. A thin clay layer just above $9 \mathrm{~m}$ overlays a sand layer which extends down to $10.5 \mathrm{~m}$ where the transition to the Hawthorn appears. The large resistance of the lower sand unit may be due to weathered limestone or more consolidated sands or cobbles. 
The borehole electrical conductivity logs are shown in Figure 15. High values of electrical conductivity are associated with increased concentrations of dissolved ions in the water and the presence of clays. Elevated dissolved ion concentrations can result from contaminants or biological activity. Lower conductivity values are associated with either lower dissolved ion concentrations, the presence of non-conducting fluids such as air or NAPL, and sands and silts. Logs from the same cluster are plotted together. The conductivity logs for G1 and G2 are the same except for the first meter below TOC. There is a discernable increase in conductivity in the sand unit about a meter above the transition into the Hawthorn. The conductivity in the sand unit is about $30 \mathrm{mS} / \mathrm{m}$, and the maximum value in the clay layers is about 150 $\mathrm{mS} / \mathrm{m}$. In G3, G4 and G5, the increase in conductivity with depth also begins in the sand unit about a meter above the transition to the Hawthorn. Conductivity in G3 is about $15 \mathrm{mS} / \mathrm{m}$ lower than in G4 and G5. Conductivity in G3 has a local minimum around $4 \mathrm{~m}$ below TOC of $21 \mathrm{mS} / \mathrm{m}$, which does not appear in G4 and G5. The maximum conductivity in the clay layers is $130 \mathrm{mS} / \mathrm{m}$. The general trend of conductivity values is the same in the G1-G2 and G3-G4-G5 clusters. In the G6-G7-G8 cluster, the conductivity in the upper 3 meters (in the vadose zone) is two orders of magnitude higher than in the first two clusters discussed. By $4 \mathrm{~m}$ below TOC, electrical conductivity trends are similar to those noted for the first two borehole clusters, although values in the sands are about $10 \mathrm{mS} / \mathrm{m}$ higher. The log for G6 exhibits a sudden increase to $84 \mathrm{mS} / \mathrm{m}$ followed by a sudden decrease to $31 \mathrm{mS} / \mathrm{m}$ at 5 to $5.5 \mathrm{~m}$ below TOC. Between 6 and 9 $\mathrm{m}$ below TOC, the log for G8 shows a gradual increase to $130 \mathrm{mS} / \mathrm{m}$, followed by a decrease to $85 \mathrm{mS} / \mathrm{m}$, closer to the conductivities in G6 and G7.

In the northern NAPL area, conductivity values in G9 reach a maximum of $2700 \mathrm{mS} / \mathrm{m}$ at $2 \mathrm{~m}$ below TOC. G10 has a smaller maximum of $1200 \mathrm{mS} / \mathrm{m}$ at the same depth. Between 3 to $4.5 \mathrm{~m}$ below TOC, conductivities are steady at about $55 \mathrm{mS} / \mathrm{m}$ in G9 and $70 \mathrm{mS} / \mathrm{m}$ in G10. At $4.5 \mathrm{~m}$, conductivities of both logs decrease until $6 \mathrm{~m}$ depth, where values of 20 and $30 \mathrm{mS} / \mathrm{m}$ occur in G9 and G10, respectively. From that depth on, conductivities increase at different rates in each borehole, until $45 \mathrm{mS} / \mathrm{m}$ at $8.5 \mathrm{~m}$ depth.

\section{Crosshole data}

The crosshole data has been processed to produce moving spectra and velocity tomograms, shown in Figures 16 - 20. Amplitude tomography was not performed. The moving spectra show the vertical distribution of amplitudes within a given frequency range, computed from the zero-offset waveforms. In each waveform received directly across from (or at zero-offset to) the transmitter, a Fast Fourier Transform of a window of thirty-two samples in the waveform is performed to produce an amplitude spectrum. Amplitudes over four samples within the spectrum are summed over the given frequency range; the sum is associated with the average time of the thirty-two sample window. This is repeated for each consecutive group of thirty-two samples over the length of the waveform to produce a plot of amplitude vs. time at a given depth or elevation. Comparing moving spectra plots computed for several different frequency ranges indicates the dominant frequencies in the data. There is no discretization in the horizontal direction.

Travel time tomography uses the first arrival times picked from the recorded multiple offset profile (i.e. one source and multiple receiver positions) waveforms for each transmitter-receiver pair, to obtain an estimate of the two-dimensional inter-borehole velocity structure based on an inversion algorithm. The inversion method is based on the relation between propagation velocity and the total travel time along a ray path between a transmitter and receiver:

$$
T=\int_{R} u(\boldsymbol{r}) d l
$$

where $T$ is the travel time, $u(r)$ is the slowness, or inverse velocity, at a coordinate in space $\boldsymbol{r}$ and $d l$ is the incremental distance along the raypath with total length $R$. When inverting the travel times for slowness, the region of interest is generally divided into cells of constant slowness. Under these discretized conditions, the equation for $T$ can be described by a set of linear equations. 
$t_{k}=\sum_{i=1}^{N} u_{i} l_{k i}$

where $t_{k}$ is the travel time of the $k$ th raypath, $u_{i}$ is the slowness estimate of the $i$ th cell, $l_{k i}$ is the length of the $k$ th raypath in the $i$ th cell, and $N$ is the total number of cells. An Algebraic Reconstruction Technique (Peterson, 1986) is used in the travel time inversion for velocities.

The depth scale on the tomograms is "depth below sea level" and has been corrected for borehole deviation. The other images use the depth below TOC and have not been corrected for borehole deviation. They are aligned with the tomograms by using the surveyed TOC elevation.

White areas on the sides of the tomograms are due to borehole deviation, i.e. they indicate that the borehole was inclined at that location. White areas inside the tomogram are locations that cannot be resolved due to inadequate ray coverage, because not enough of the arrival times of waves through that region could be picked. Diagonal features are generally considered to be inversion artifacts. The presence of spheroidal, non-geologic shapes also indicates problems with the inversion. Various corrections were made, without improvement in the images, and therefore we concluded that the geometric effects arising from the borehole deviation dominate what is seen in the tomograms. This may be due to possible inaccuracies in the deviation survey.

Seismic velocities range from 1800 to $2200 \mathrm{~m} / \mathrm{s}$. For $1-5 \mathrm{kHz}$ frequency, this gives wavelengths on the order of 36 to $220 \mathrm{~cm}$. Table 2 shows that this velocity range covers clays and sands. Radar velocities ranged from 0.057 to $0.070 \mathrm{~m} / \mathrm{ns}$.

For the G1-G2 borehole pair, moving spectra were calculated over the $0-2 \mathrm{kHz}$ and $3-5 \mathrm{kHz}$ range (Figure 16). The largest amplitudes are shown in red, and the smallest are in blue. The arrival time is indicated by the first color change from blue (no energy) to green, yellow or red. Arrival times can only be viewed in a relative sense and cannot be accurately picked from this presentation because of the amplitude and timescale averaging described earlier. High amplitude layers at both frequency ranges occur from 2.5 to $3.5 \mathrm{~m}$, 4.5 to $5.5 \mathrm{~m}$ and below $8 \mathrm{~m}$ from TOC. However, the $3-5 \mathrm{kHz}$ spectra show reduced amplitudes at about 2.8 and $4.8 \mathrm{~m}$. The upper two layers occur in sands, as indicated by the CPT-derived lithology, but the CPT logs do indicate small fluctuations in F ratio and piezo pressure near 2.8 and $4.8 \mathrm{~m}$, respectively (see Figure 14). The deeper high-amplitude layer coincides with the silts and clays. The $3-5 \mathrm{kHz}$ energy is much stronger in the clay layer than the $0-2 \mathrm{kHz}$, while the $0-2 \mathrm{kHz}$ energy is stronger through the sands.

At $6.5 \mathrm{~m}$, there is a layer of almost no energy transmission. Some of the $0-2 \mathrm{kHz}$ energy appears at greater travel times; this may be refracted energy from the high transmission zones. This low energy layer corresponds to the silty-sands noted in the lithology and to the beginning of increasing conductivities. Another layer of reduced energy transmission for both frequency ranges occurs at $3.5 \mathrm{~m}$, which corresponds to the silty-sand noted in the lithology log.

In the G1-G2 borehole pair, both radar and seismic tomographic data were obtained. In the seismic tomogram, the high velocity layer at the bottom corresponds to the clays and silts. The region of low amplitudes at the transition to the Hawthorn at $6 \mathrm{~m}$ cannot be resolved, although this does appear to be a low velocity region based on the zero offset data. Above that, the distribution of velocities is distorted due to geometry effects.

The moving spectra radar plot shows high amplitudes through the vadose zone, from about 1.5 to $2 \mathrm{~m}$ below TOC. The high amplitude energy above $1.5 \mathrm{~m}$ is produced by test waves through air. The water table appears at about $2.25 \mathrm{~m}$ below TOC, where arrival times sharply increase. Amplitudes are high through the sands, and decrease at the point where borehole conductivity values increase. The maximum radar amplitudes through the sands coincide with the high seismic amplitudes just below $5 \mathrm{~m}$ below TOC. 
In the radar tomogram, the transition into the Hawthorn is clearly seen by a low velocity layer. The high velocity layer above the water table corresponds to the vadose zone. Between the high and low velocity layers, the tomogram does not provide any reliable information due to inversion/geometry effects.

A similar pattern of high and low amplitudes can be seen in the seismic moving spectra plots for the G3G4-G5 line, in Figure 17. In G4-G3, more energy is transmitted in the 1-2 and 2-3 kHz range compared to the $4-5 \mathrm{kHz}$ range. A zone of no energy transmission occurs at the transition to the Hawthorn. Another zone of reduced energy transmission occurs at $4 \mathrm{~m}$ depth from TOC. This zone's width increases as the frequency range increases, from $\sim 0.5 \mathrm{~m}$ at $1-2 \mathrm{kHz}$, to $\sim 1.5 \mathrm{~m}$ at $4-5 \mathrm{kHz}$. The lithology log indicates that this is within sands, but the CPT logs of tip, sleeve and piezo pressures do exhibit fluctuations at this depth. This is also the same elevation that the local minimum in conductivity of G3 was noted (at $\sim 4 \mathrm{~m}$, Figure $15)$.

In all the subsequent borehole pairs, the moving spectra analysis of the seismic data was done only for the $3-5 \mathrm{kHz}$ range. The relative distribution of high and low amplitude zones over depth for G5-G4 and G4-G3 are the same (Figure 17). The energy transmission through G4-G5 is much greater than through G4-G3, because of the greater borehole separation between the latter pair. In G5-G3, where transmission occurs over approximately twice the distance of the other boehole pairs, the amplitudes through the upper two more transmissive zones are reduced relative to G4-G3 and G5-G4, but are not reduced through the lower transmissive zone.

In the G3-G4-G5 line, seismic crosshole data was obtained in all borehole combinations; and radar crosshole data was obtained between between G4-G3 only. These tomograms are shown in Figure 18. Borehole G4 had the greatest amount of deviation, which was about $4 \mathrm{ft}$ over the $30 \mathrm{ft}$ depth of the hole. This can be seen from the white area on the G4-side of the tomograms. The seismic tomogram for G5-G4 is dominated by inversion/geometry artifacts, and is not shown because it cannot be correlated to any geological information. The G4-G3 seismic tomogram shows a higher velocity layer through the sands, decreasing with depth until the area of poor seismic transmission, which could not be resolved. Below this, velocities are low, increasing slightly at the bottom. The tomogram for G5-G3 is consistent with G4-G3. The G4-G3 radar moving spectra plot and tomogram are similar to G1-G2, showing the high velocity vadose zone, the low velocity transition into the Hawthorn and the distorted section through the sands. The moving spectra plot shows an increasing arrival time through the sands, that follows the borehole deviation.

In the G6-G7-G8 line, cross-hole seismic and radar data were obtained between G6-G7 only. The upper part of the seismic data was so strongly attenuated that there were not enough pickable arrival times to perform the inversion. The moving spectra for seismic energy between G6 and G7 shows that seismic energy transmission down to $8 \mathrm{~m}$ is extremely poor (Figure 19). This is attributed to the proximity of the G6 to the rotary steam drilling treatment area. While the lithology log indicates sands in this area, and consequently higher amplitudes would be expected, the presence of a vapor phase or a mixed soil profile could explain the large attenuation in seismic energy. While most of the vapor introduced by the remediation would have condensed by this time, residual air may not have dissolved into the surrounding groundwater. Transmission through the lower clay layers is strong, as for the other borehole pairs, suggesting that rotary steam drilling did not penetrate this deep.

The radar moving spectra plot (Figure 19) is for amplitudes within the $80-120 \mathrm{MHz}$ range, despite the fact that the data was obtained with a $200 \mathrm{MHz}$ antenna. The increased source signal frequency did not produce an increase in the frequency of the received signal because the higher frequencies are more attenuated. The water table occurs at about $2.5 \mathrm{~m}$ below TOC; the arrival time of the EM wave linearly increases from 1 to $2 \mathrm{~m}$, corresponding to an increase in water saturation as the water table is approached. Comparison with the radar tomogram shows that high velocities correspond to high amplitudes. The occurrence of the high velocities due to entrapped air is consistent with the strong attenuation seen in the zero-offset seismic data. Below this, the transition into the Hawthorn is marked by alternating layers of low to high to low velocities. The lithology log does indicate alternating sequences of clayey, sandy and silty layers, which may explain this, or it may be due to fluid heterogeneities. 
Finally, in the G9-G10-G11 line, seismic tomographic data and zero offset radar data were obtained for G10-G9 (Figure 20). Seismic amplitudes are low down to $5 \mathrm{~m}$ below TOC. The lithology log shows that this region has layers of silts and clays. A high amplitude zone is centered around $6 \mathrm{~m}$, where the lithology $\log$ shows sands. A reduced amplitude zone occurs between 6.5 and $7.5 \mathrm{~m}$, where the lithology $\log$ indicates sands, but pressures in the CPT logs do fluctuate, indicating the presence of some heterogeneity. Conductivities also have a local minimum in this area. Seismic travel times could only be picked from the high amplitude layer between 5.5 and $6.5 \mathrm{~m}$ depth, and the resulting tomogram does not have the required aspect minimum aspect ratio of 1:1 and is therefore not shown. The moving spectra radar amplitudes are similar to the seismic amplitude distributions

\section{Conclusions}

The first field test provided important information regarding the seismic and radar transmission properties of the Northeast site, general geological structure, and a measure of the extent of heterogeneity between the different locations surveyed. This information will be used with lab measurements to assess the sensitivity of the seismic methods as well as design future field work. The borehole and cross-hole data show similar structure in the south NAPL area, except for the zone disturbed by steam drilling. Low amplitude seismic zones appear fairly consistently at around 7.5 to $8 \mathrm{~m}$ depth. There is another low amplitude zone at about 4 $\mathrm{m}$ depth. The low amplitude may be due to the attenuating nature of the layer itself, or the transition between two distinct layers. The lithology information does indicate changes in these zones. The presence of lithologic contrasts, specifically from higher pemeability sands to lower permeability silts and clays, also indicate potential locations of NAPL, as they could be flow barriers to downward NAPL migration.

The seismic measurements detect formation material or property changes that do not appear in the CPTderived lithology, however they do for the most part correspond to fluctuations in the CPT pressure logs. The higher frequency seismic data detect features that are not distinguished in the lower frequency data. The high seismic amplitudes encountered below 8 to $9 \mathrm{~m}$ depth are surprising, given that clays are often very attenuating to high frequency seismic energy. Geologic logs in the areas of the surveys note the presence of carbonate inclusions, gravel and carbonate layers in these clays below $10 \mathrm{~m}$ depth. There are also observations of weathered limestone/clay/shells and phosphate, and sandy clay where the sand is very fine, slightly hard and brittle.

Radar transmission also declines through the low seismic amplitude zone at 7.5 to $8 \mathrm{~m}$ depth, but does not recover towards the transition to the Hawthorn as the seismic transmission does, due to the attenuating nature of the clays to radar. The radar data clearly indicate the location of the water table and transition to the vadose zone.

All the measurements made in the north NAPL area indicated a different structure from the south, specifically the presence of an attenuating layer from about 3 to $5 \mathrm{~m}$ depth. Seismic transmission was poor, except for one area centered at about $6 \mathrm{~m}$ depth and another between 7.5 and $8 \mathrm{~m}$. In addition, because of borehole deviation, surveys could only be made down to about $8 \mathrm{~m}$ depth.

The moving spectra profiles, conductivity and CPT logs were generally consistent with one another. The moving spectra profiles provide averaged properties over the borehole span. Without the horizontal discretization provided by tomography, much of the information that could potentially be derived from the data collected cannot be utilized. Therefore, this dataset can only indicate general structural features, and not liquid phase heterogeneities. Travel-time tomography was not reliable due to the deviation of the boreholes from vertical. This deviation should be correctable in the tomographic inversions if the borehole geometry is known accurately. However, this was not the case here, either due to possible inaccuracies in the survey or the magnitude of borehole deviation.

The information obtained in the first year of the project will be utilized in the second year field work. Surveys will be performed in new, sonic-drilled boreholes in the south NAPL area; minimal deviation would be expected for this type of drilling. The new borehole locations will coincide with those installed in 
the first-year. Several of them will be core-drilled to obtain core near the CPT-installed boreholes for ground-truth.

The fractured-rock case will also be tested in FY02. At the Idaho National Environmental and Engineering Laboratory, Test Area North (INEEL-TAN) site, time-lapse surveys will be performed to investigate bioremediation-induced changes in the area of the TCE hot-spot. The INEEL-TAN site has known TCE contamination and an unknown remaining DNAPL source zone. Under the EMSP program, we performed crosswell seismic surveys of the TAN source-zone, which showed the potential of this technology for fracture-zone characterization (1996-1998). Since this time, bioremediation of TCE by lactate injection has been ongoing. Repeated surveys at this site will provide time-lapse information for bioremediationinduced changes, as well as updated baseline information before the installation of new monitoring wells, planned for FY03. The new monitoring wells will provide a unique opportunity to validate bioremediation of the TAN site, as well as improve on remediation.

\section{Acknowledgment}

This work is funded by the Subsurface Contamination Focus Area of the Environmental Management Program of USDOE. We gratefully acknowledge David S. Ingle of USDOE, who is the Pinellas site manager, and his staff of MACTEC-ERS, for providing us with site access and support. Tom Daley and Susan Hubbard of LBNL provided thorough and helpful reviews of this report. 


\section{References}

Daley, T. M., E. L. Majer and J. E. Peterson, Crosswell Seismic Imaging in a Contaminated Basalt Aquifer - Final Report, LBNL report no. LBNL-45533, 2001

Daley, T. M., Feighner, M. A., Majer, E. L., Monitoring underground gas storage in a fractured reservoir using time lapse VSP, LBNL report no. LBNL-44876, 2000.

Geller, J. T. and L. R. Myer, Ultrasonic imaging of organic liquid contaminants in unconsolidated porous media, Journal of Contaminant Hydrology, Vol. 19, No. 3, 85-104, 1995.

Geller, J. T., M. B. Kowalsky, P. K. Seifert and K. T. Nihei, Acoustic Detection of Immiscible Liquids in Sand, Geophysical Research Letters, Vol. 27, No. 3, 417-420, 2000.

Marion, D., A. Nur, H. Yin and D. Han, Compressional velocity and porosity in sand-clay mixtures, Geophysics, Vol. 57, No. 4, 554-563, 1992.

Peterson, J. E., Jr., The Application of Algebraic Reconstruction Techniques to Geophysical Problems, Thesis (Ph. D. in Geophysics)--University of California, Berkeley, May 1986.

Pyrak-Nolte, L. J., Morris, J.P., Single fractures under normal stress: The relation between fracture specific stiffness and fluid flow, International Journal of Rock Mechanics and Mining Sciences, Jan-Feb, 2000, Vol. 32, No. 1-2, 245-262, 2000.

PyrakNolte, LJ. The seismic response of fractures and the interrelations among fracture properties, International Journal of Rock Mechanics and Mining Sciences and Geomechanics Abstracts, Vol. 33, No. 8, 787+, 1996.

Pyrak-Nolte, L. J., Myer, L. R., Cook N. G. W., Transmission of Seismic Waves Across Single Natural Fractures, J. of Geophysical Research-Solid Earth and Planets, Vol. 95, No. B6, 8617-8638, 1990.

Roberts on, P. K. and R. G. Campanella, Interpretation of Cone Penetration Tests. Part 1: Sand, Canadian Geotechnical Journal, Vol. 20, No. 4, 718-733, 1983.

U.S.D.O.E., Northeast Site NAPL Characterization Report, Document Number N0031600, Grand Junction, CO, October, 2000a.

U.S.D.O.E., Northeast Site NAPL Characterization Report Addendum, Document Number N0037300, Grand Junction, CO, October, 2000b.

U.S.D.O.E., cost and Performance Report - Dual Auger Rotary Steam Stripping, Pinellas Northeast Site, Largo, Florida, Innovative Treatment Remediation Demonstration, April, 1998. 


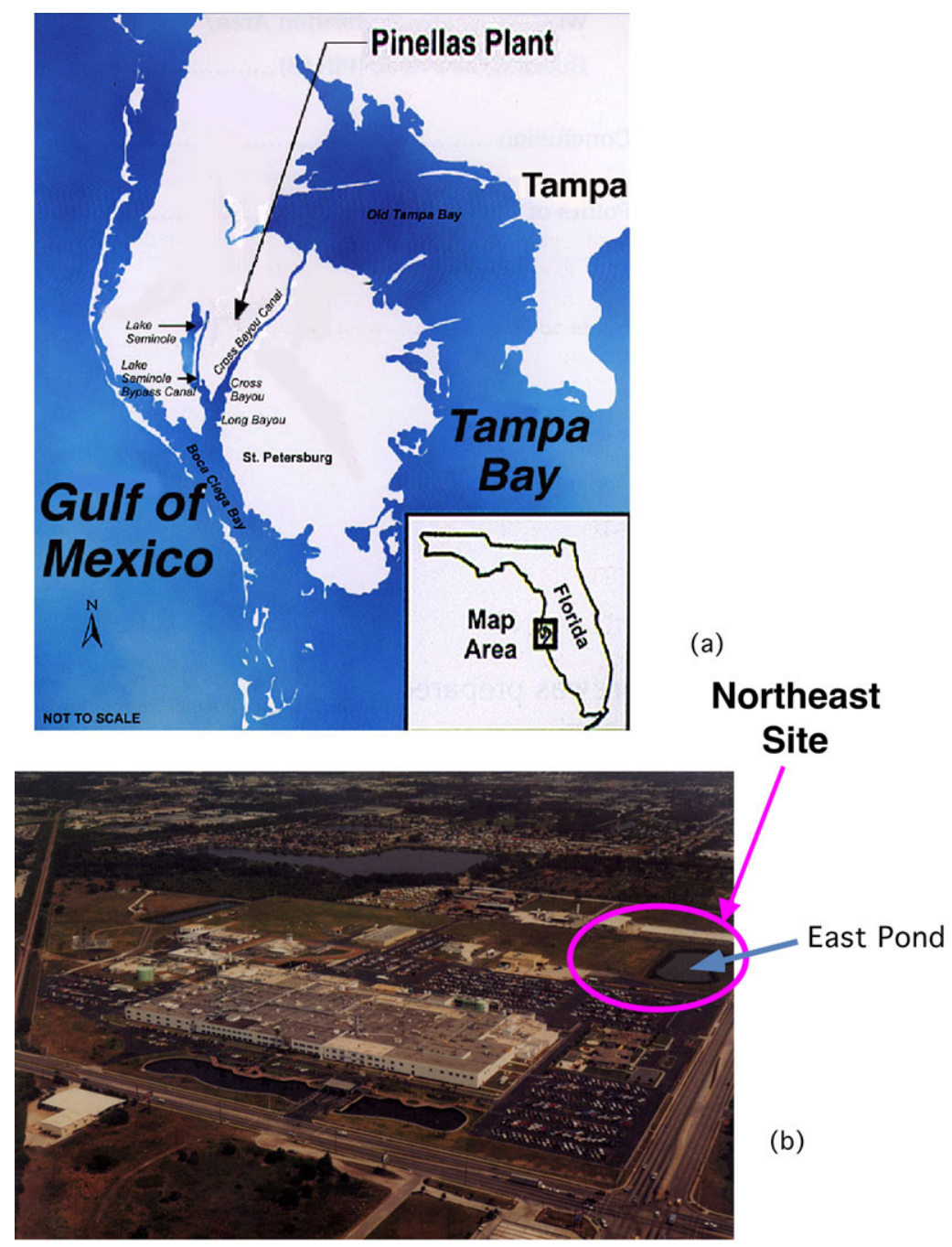

Figure 1. Location of Northeast Site at Pinellas STAR Center. (1) map of Tampa Bay area, (b) aerial photograph of Star Center. 


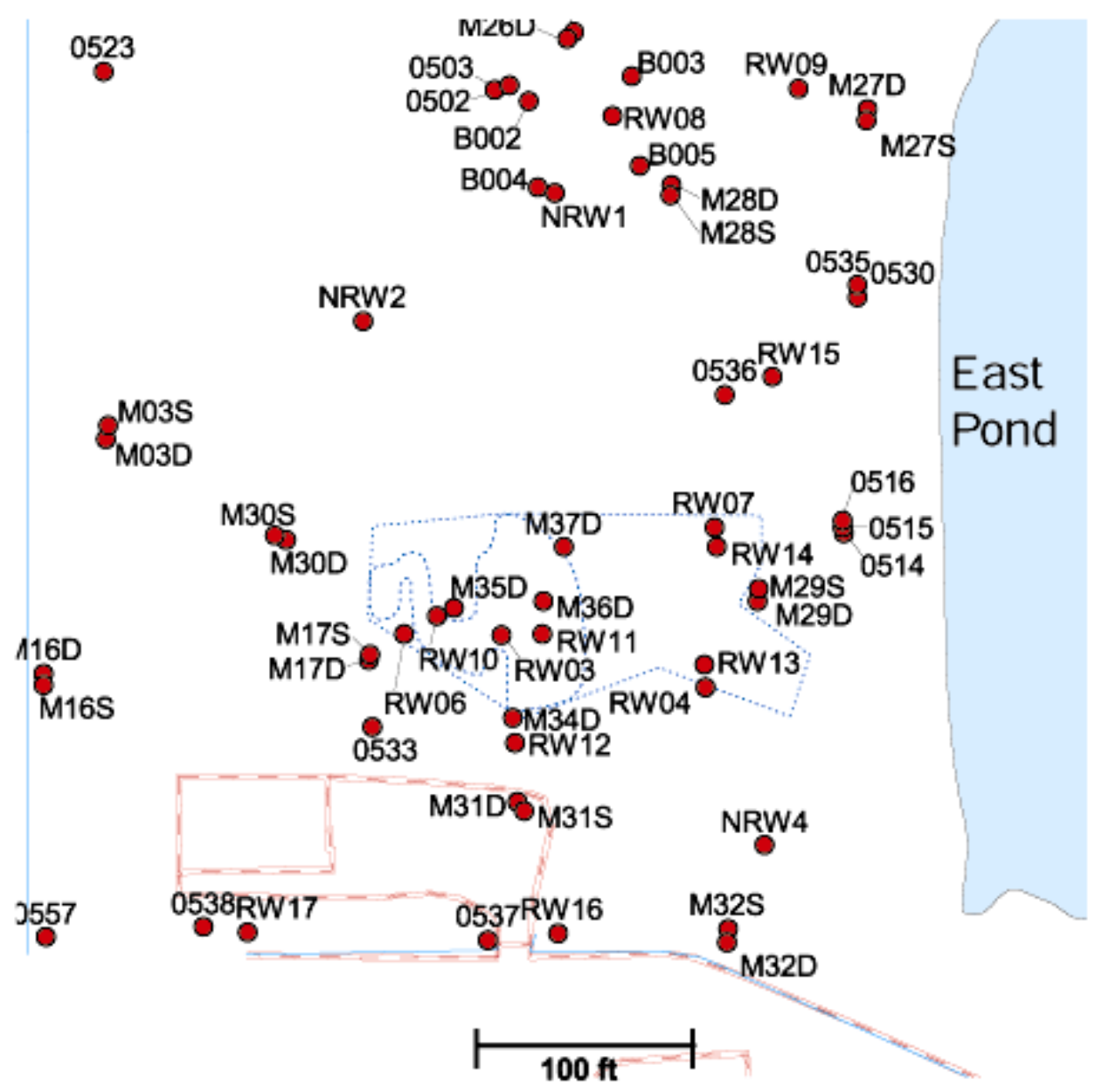

\section{LEGEND}

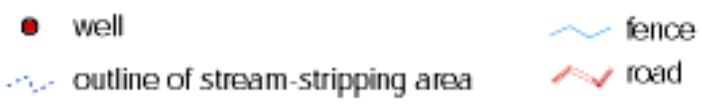

Figure 2. Plan of Northeast Site showing locations of monitoring and recovery wells, and the area of the rotary steam-stripping treatment. 


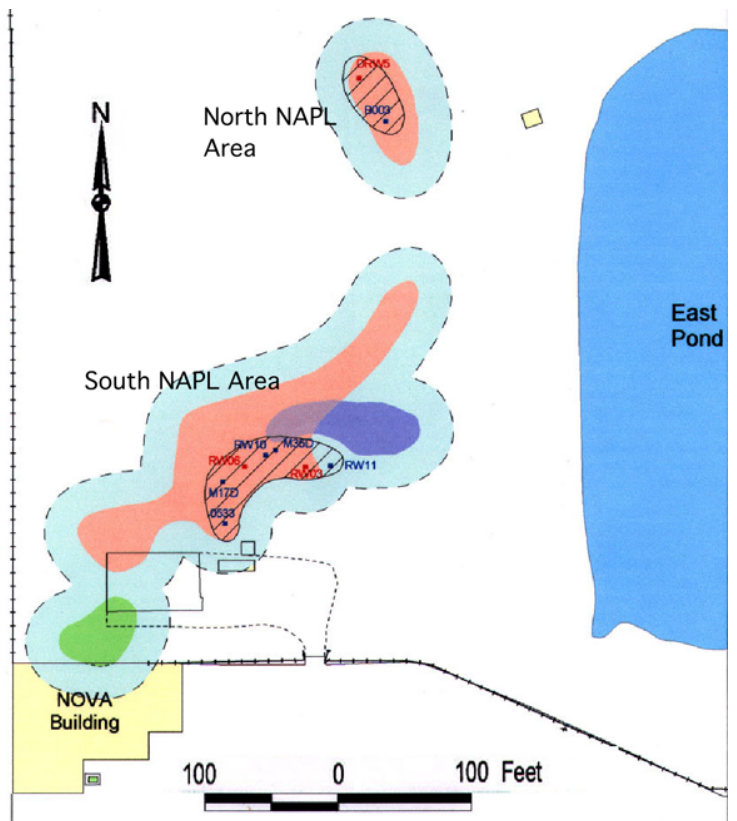

Approximate NAPL Areas

TCE and Toluene

Methylene Chloride

cis-1,2-DCE

$\square$ Oil

NAPL, Accounting for Uncertainties

- Well with Visual NAPL Identification

- Well Sampled for NAPL in October 2000

Figure 3. Approximate NAPL areas at Northeast site. 


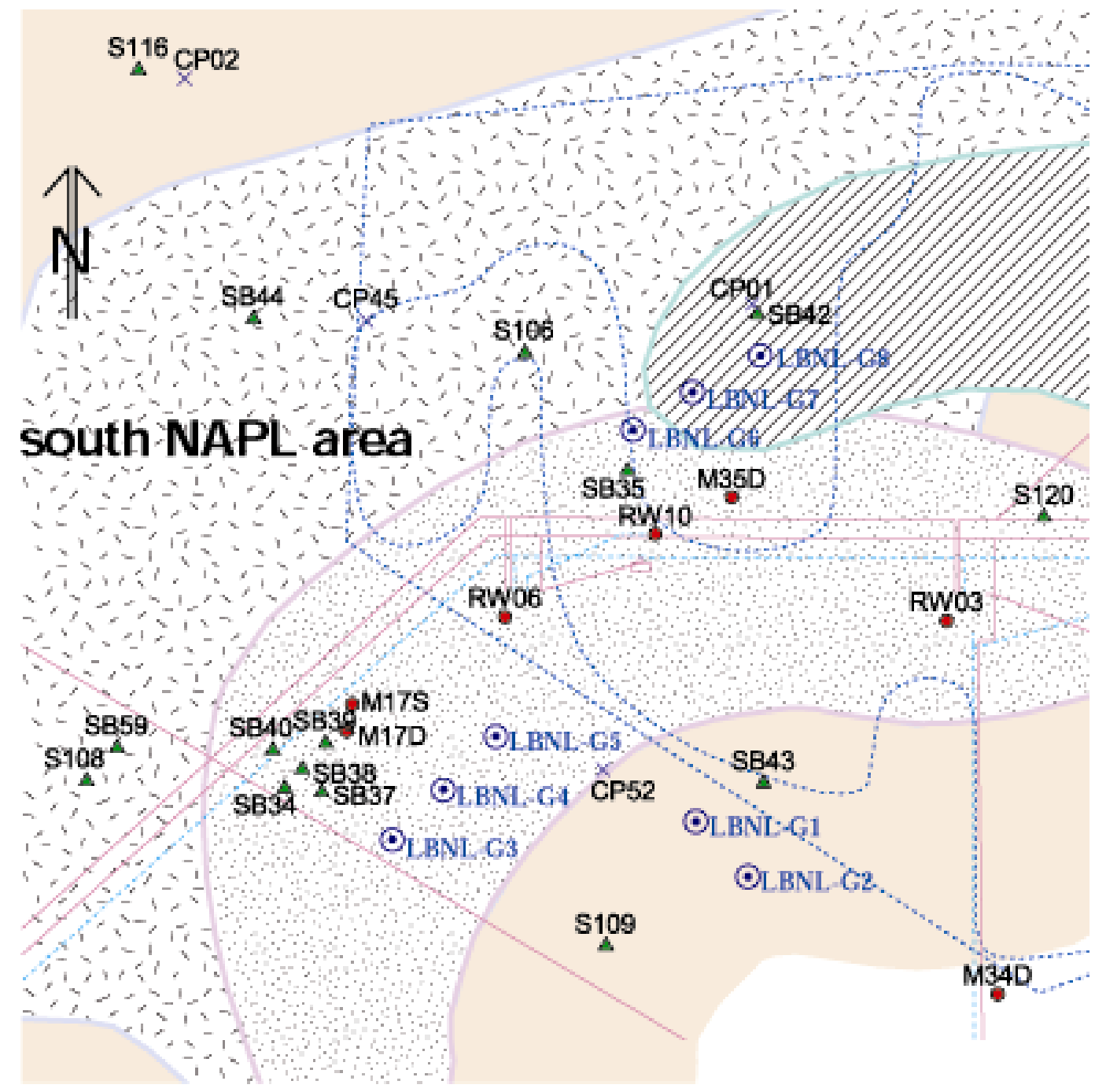

$10 \mathrm{ft}$

\section{LEGEND}
$\Delta$ soil boring
-1. TCE + toluene NAPL
fence
- well
$\times \mathrm{cpt}$
methylene chloride NAPL
road
NAPL plume halo
pipe
$\odot$ LBNL borehole
utility

oil $\quad \ldots$ outline of stream-stripping area

Figure 4. Location of geophysical survey boreholes in south NAPL area 


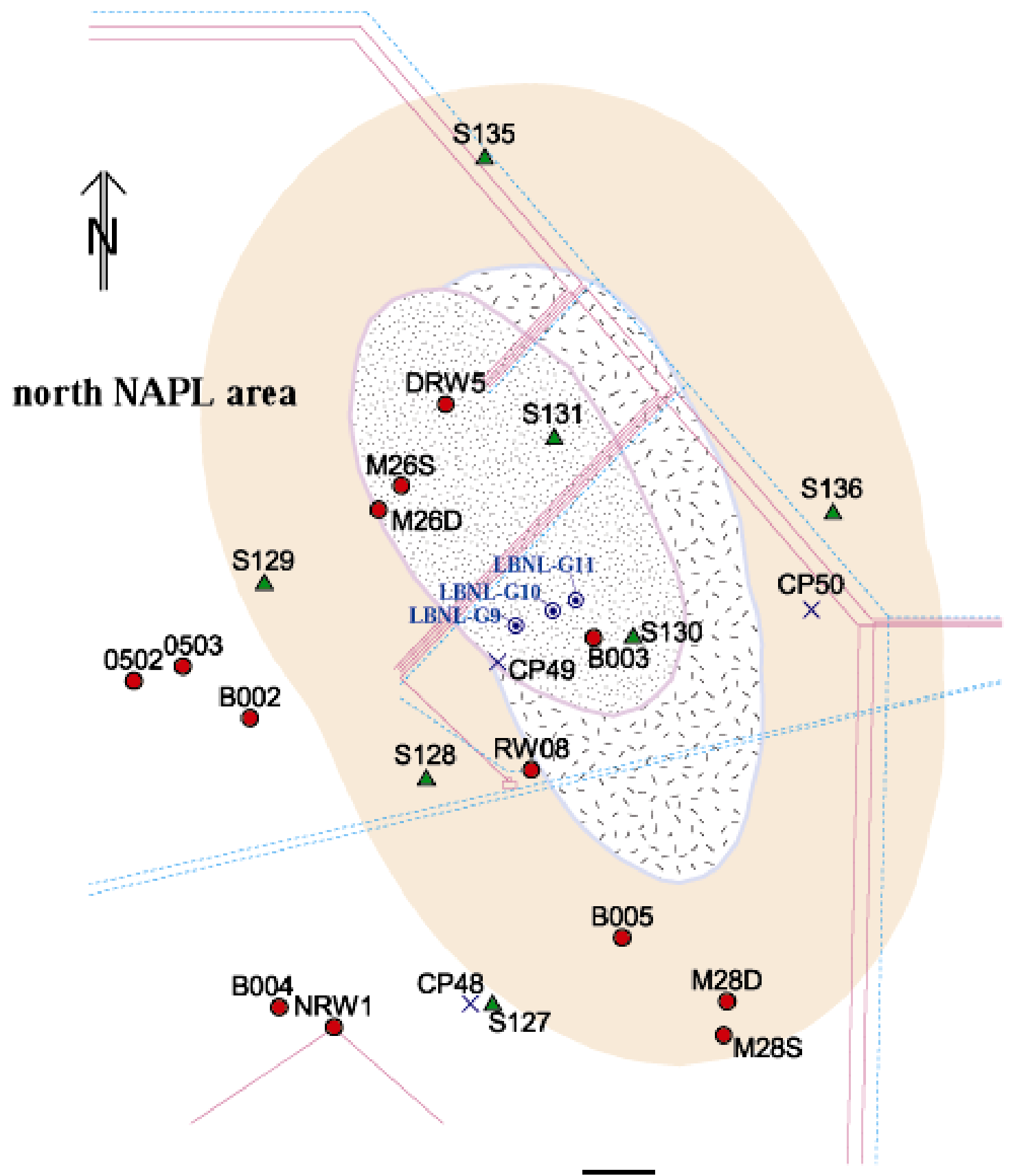

\section{LEGEND}

$\overline{10 \mathrm{ft}}$
A soil boring
oil
- well
$\times \mathrm{cpt}$
TCE + toluene NAPL
pipe
- LBNL borehole
NAPL plume hab

Figure 5. Location of geophysical survey boreholes in north NAPL area. 


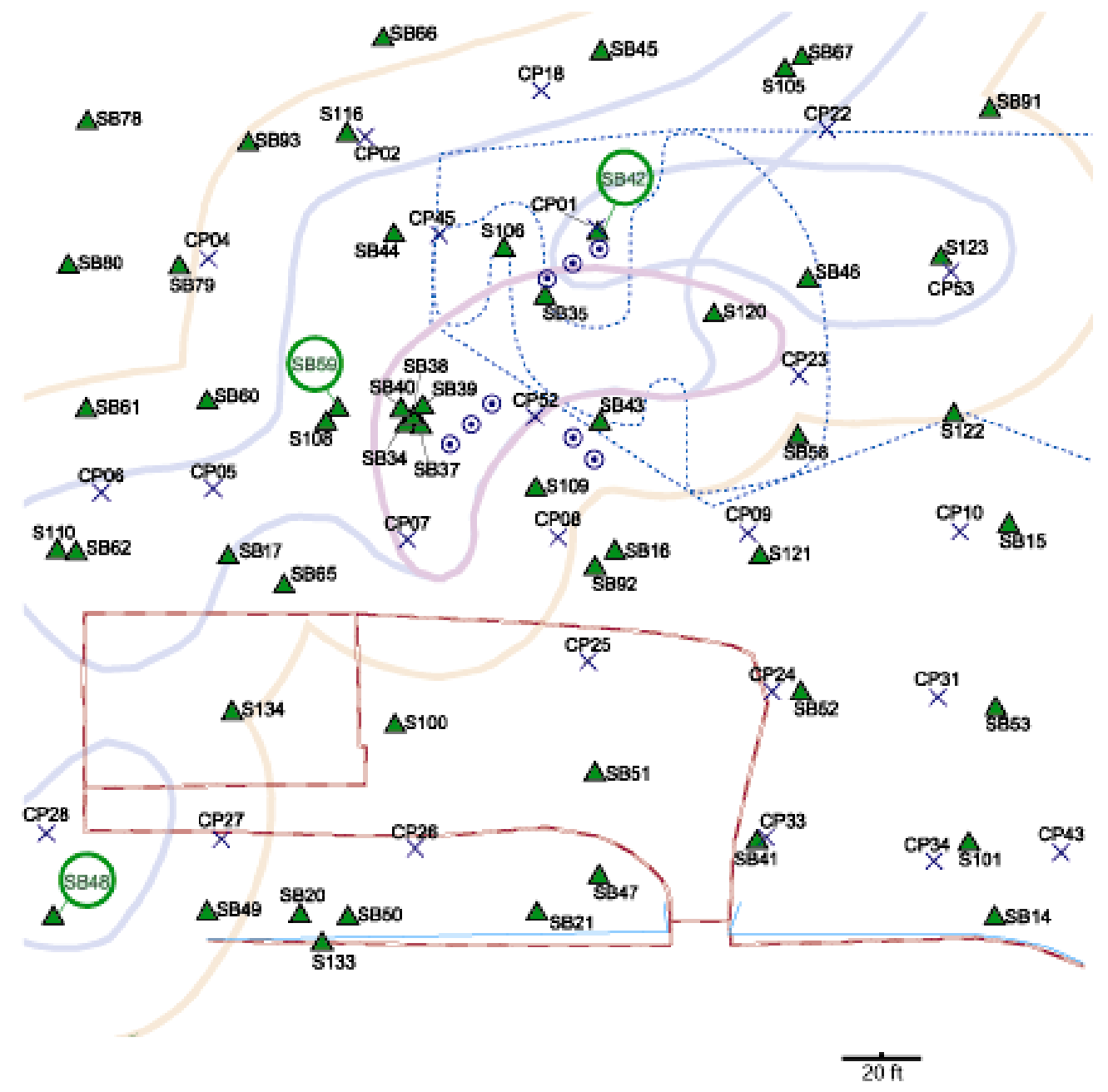
$\Delta$ soil boring site
outline of NAPL plume
..... Outline of steam-stripping arca
$\times c p t$
outline of plume halo
- road
$\odot$ LBNL borehole
_ outline of oil plume
fence

Figure 6. Location of soil borings from which grab samples were obtained. 


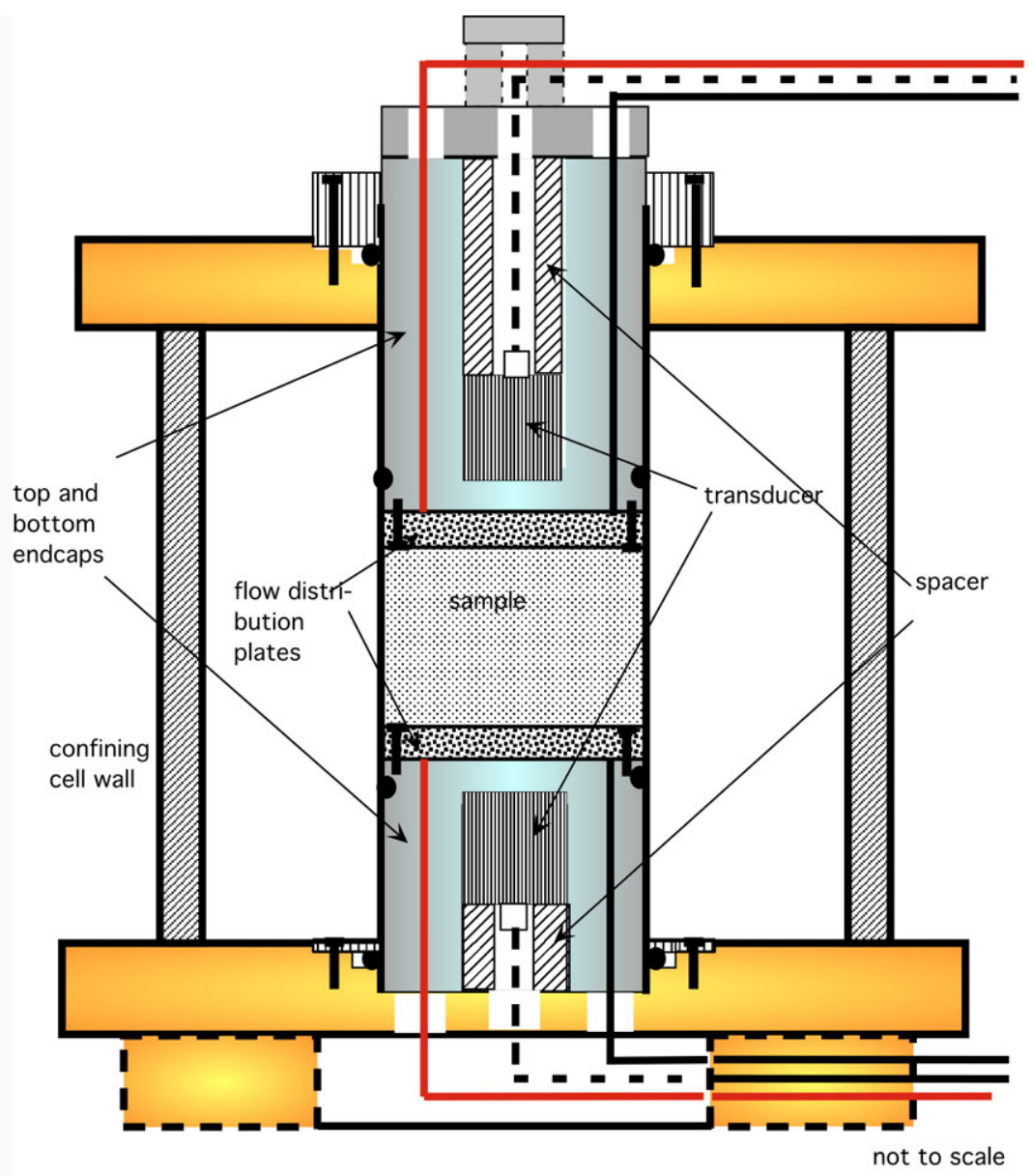

Figure 7. Schematic cross-section of triaxial test cell for measurement of P-wave propagation. 


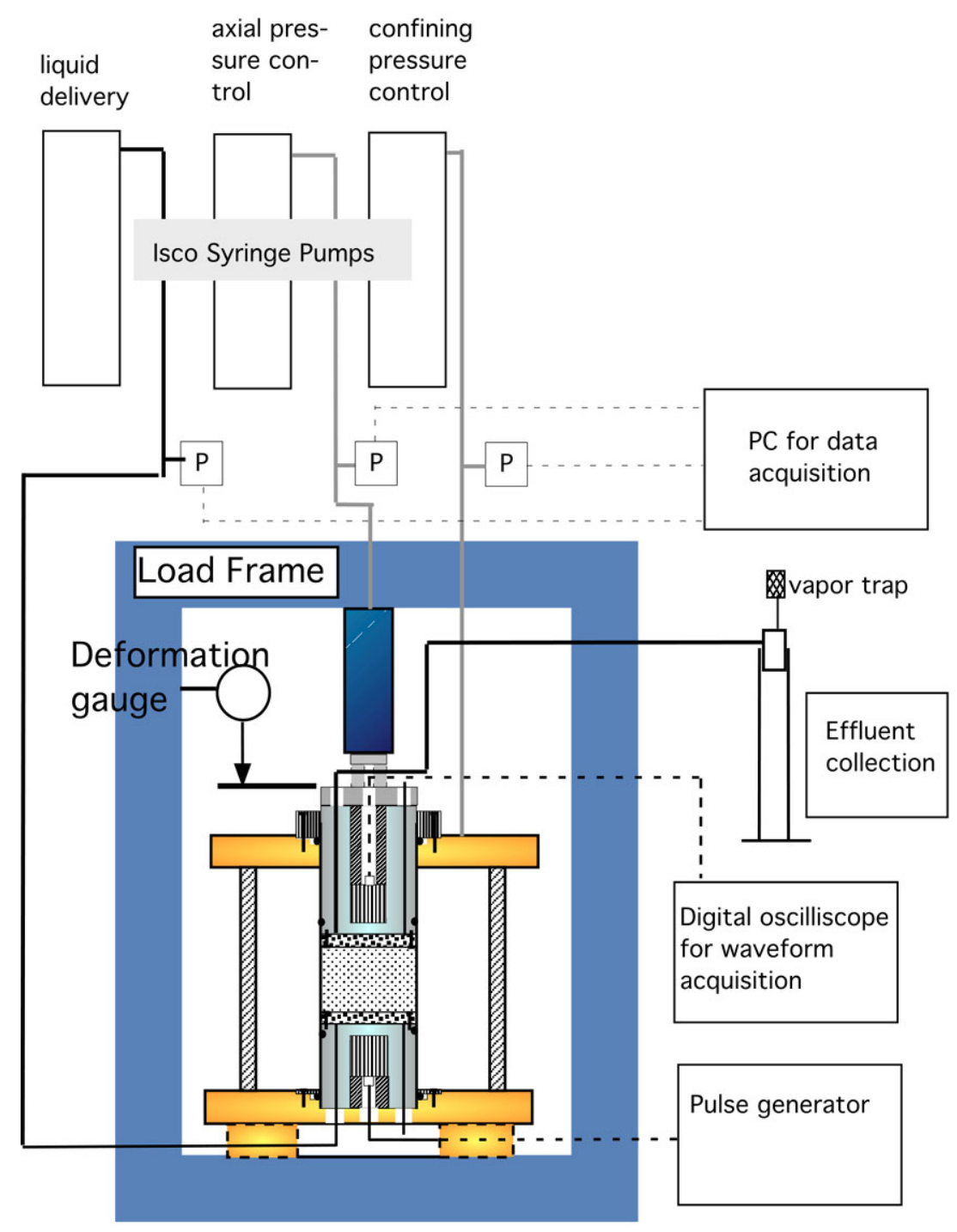

Figure 8. Schematic of triaxial test cell and supporting equipment for P-wave measurement through soils with varying fluid saturation. 
082101

w ater saturation of sb4 8 -9,10,11 - from dry to first appearance of effluent from sam ple

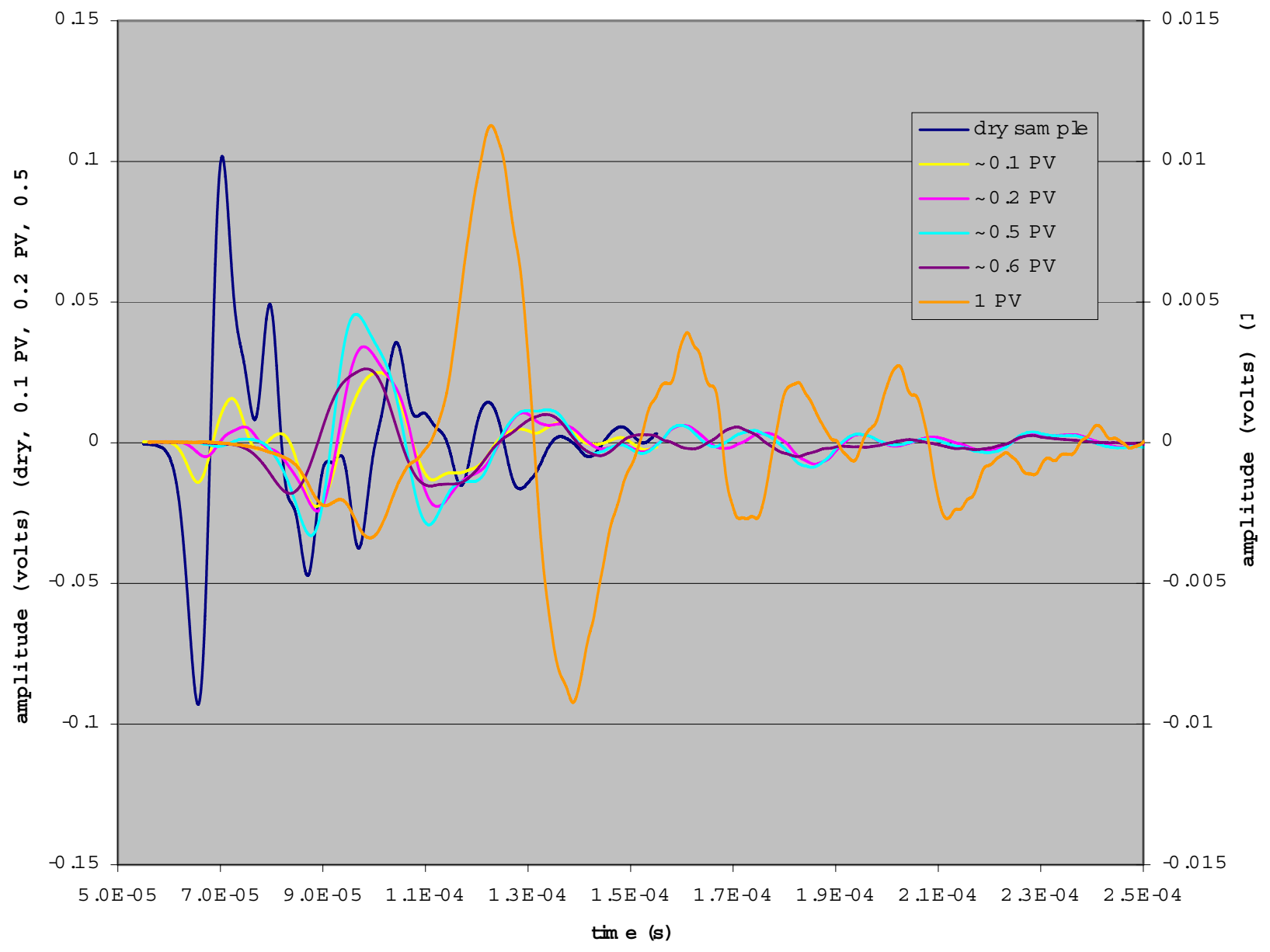

Figure 9. P-wave propagation through SB48-9, 10, 11 during water saturation, $\mathrm{PV}=$ pore volume. 
$08 / 21-08 / 23 / 2001$

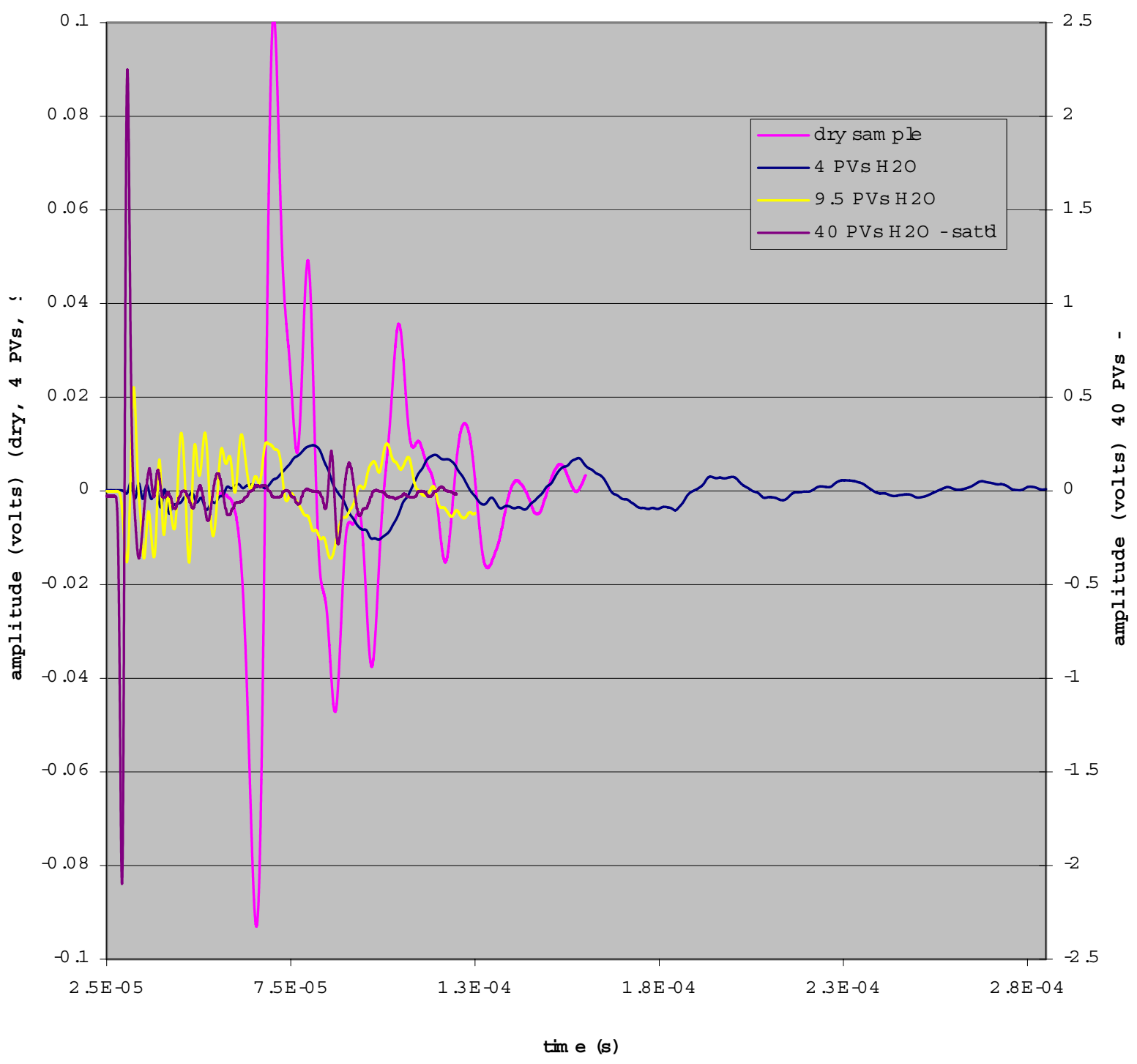

Figure 10. Water saturation of SB48-9, 10,11 and appearance of high frequency energy. 


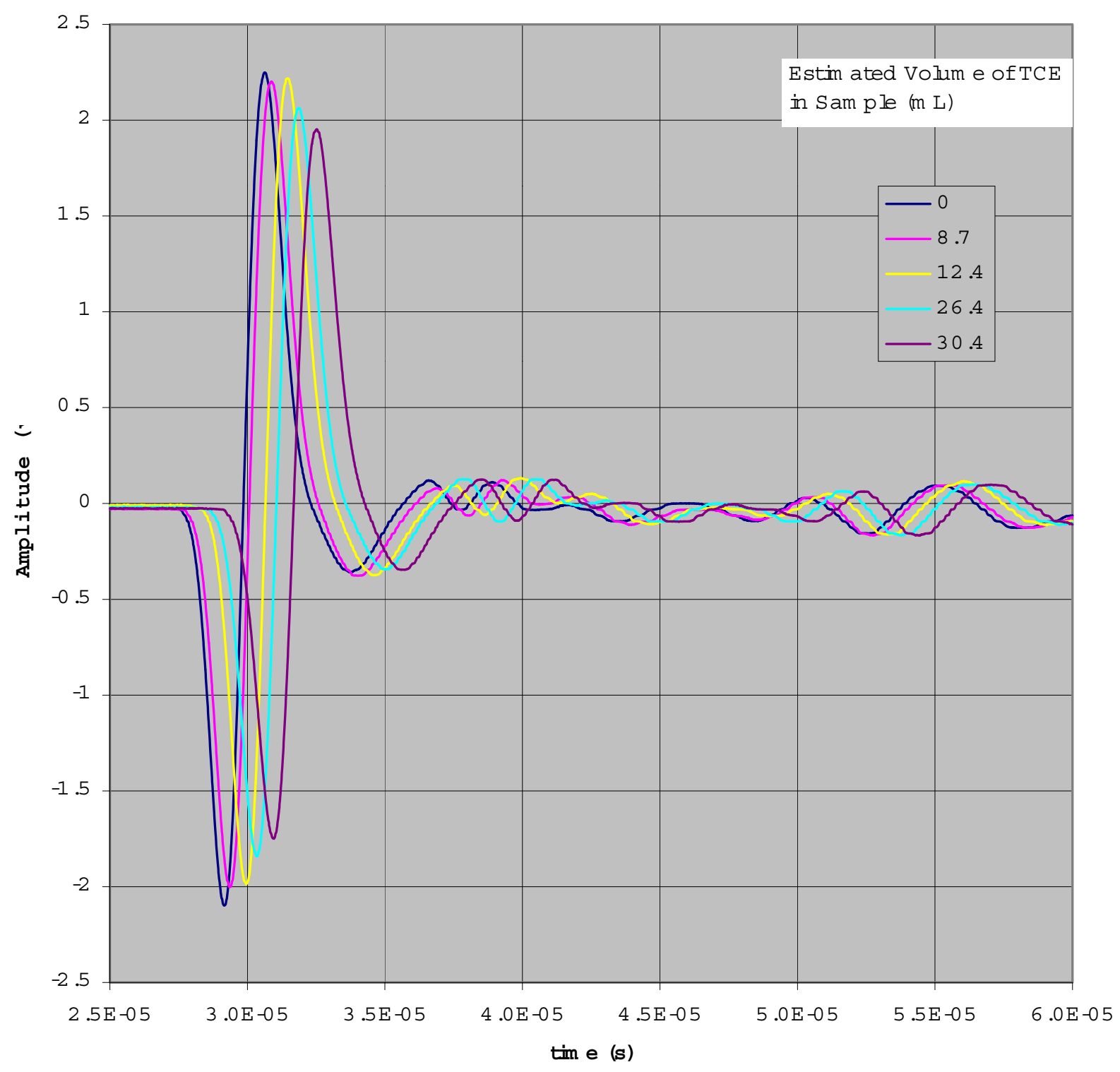

Figure 11. P-waves through SB48-9, 10, 11 during injection of TCE. 

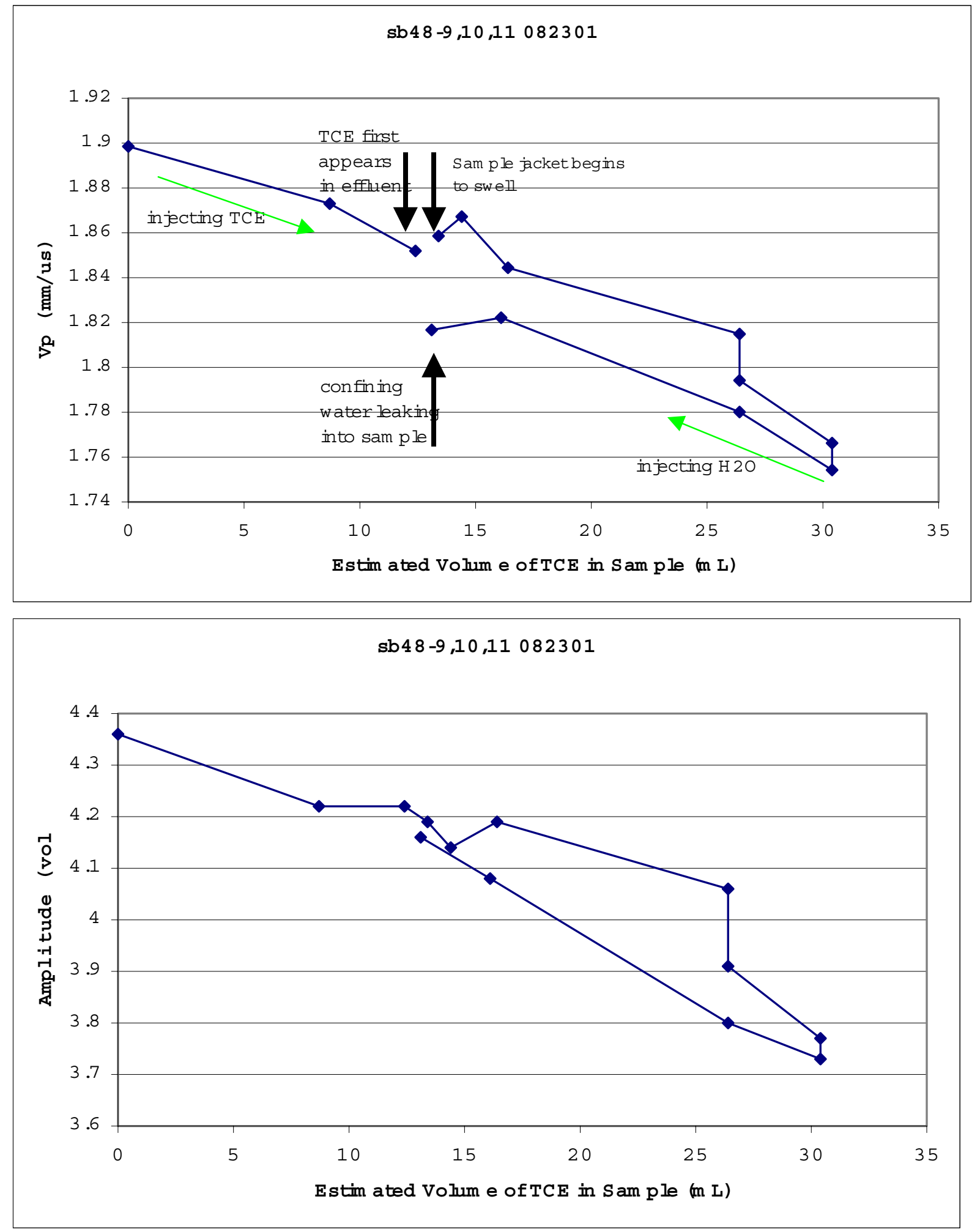

Figure 12 Measured P-wave velocity and amplitude of first arrival through SB48-9,10,11 during TCE injection 


\section{P inellas soil sam ples}

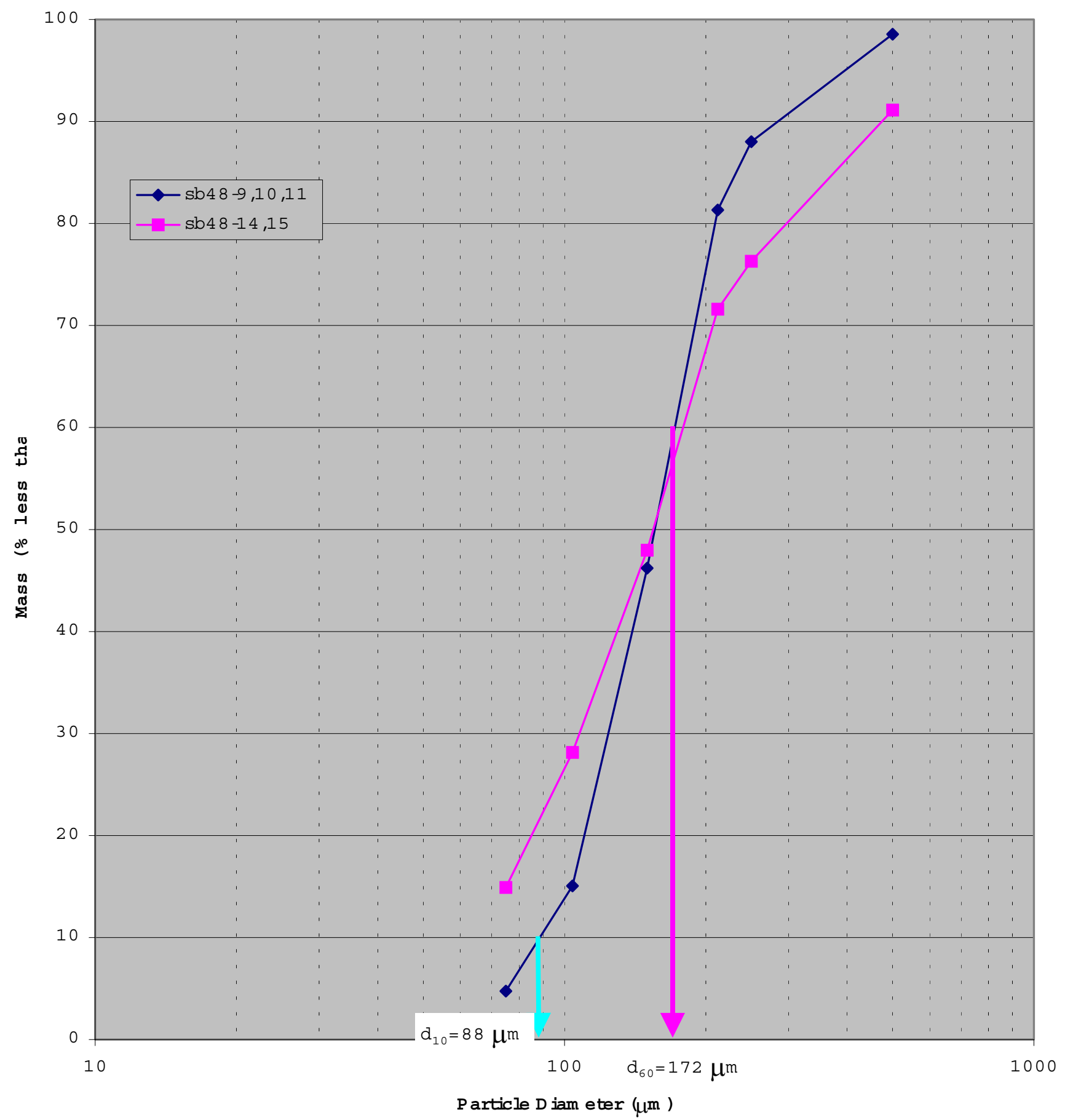

Figure 13. Grain size analysis of composite grab samples from the Northeast site. 

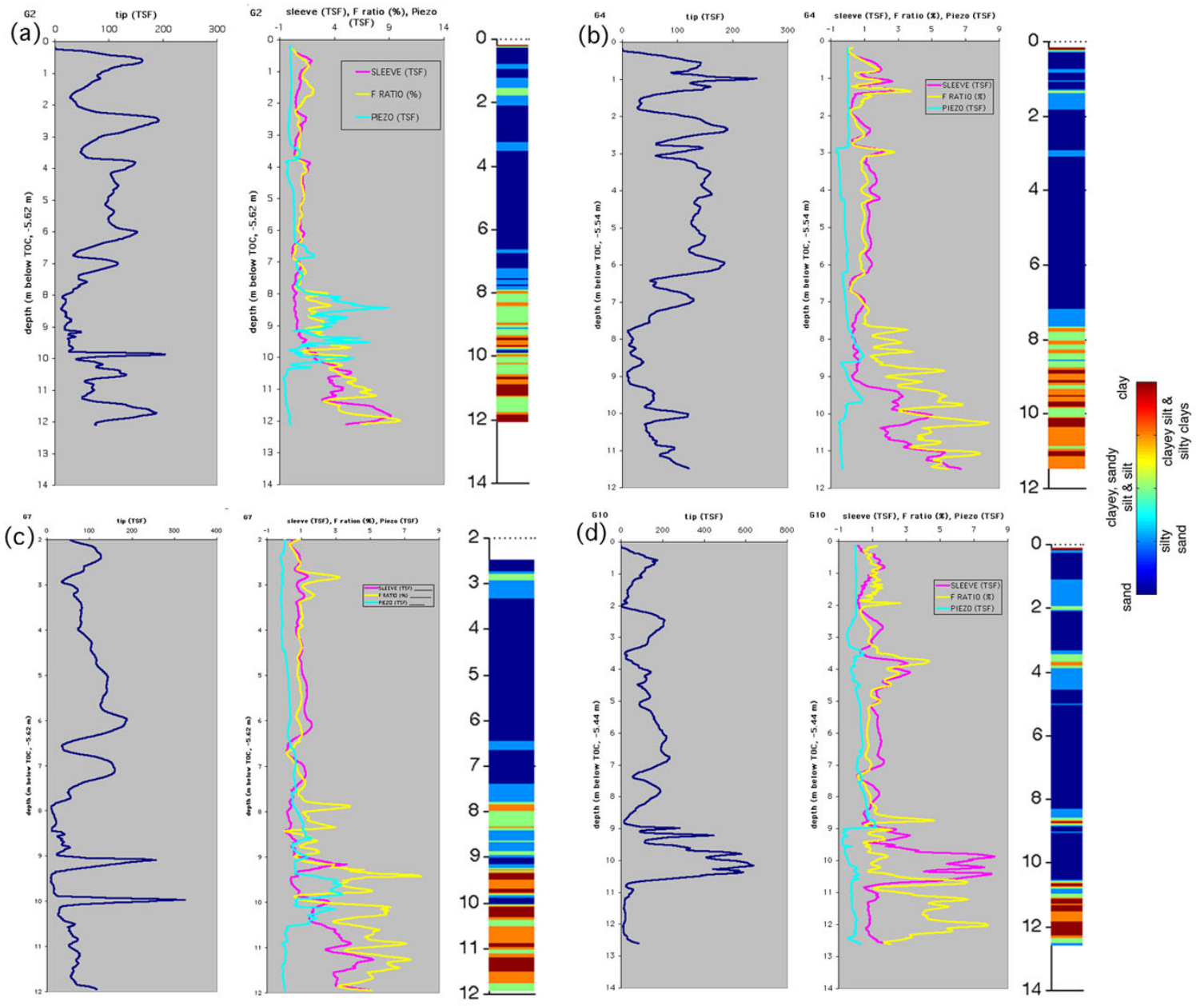

Figure 14. CPT logs for boreholes (1) G2, (b) G4, (c) G7 and (d) G10. 
(a)

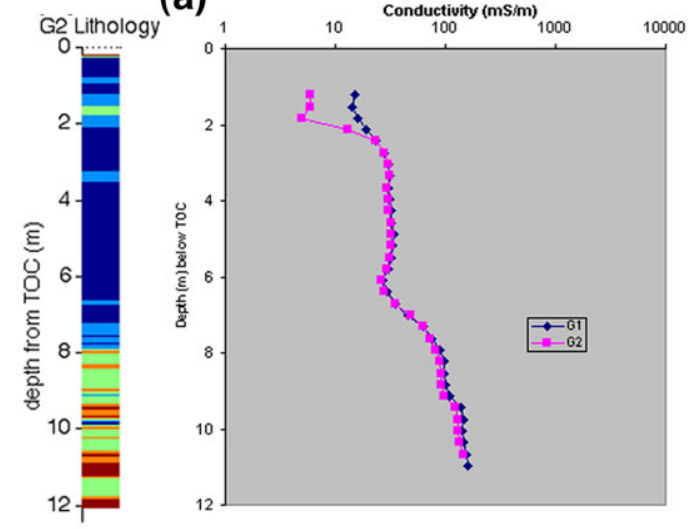

(c)

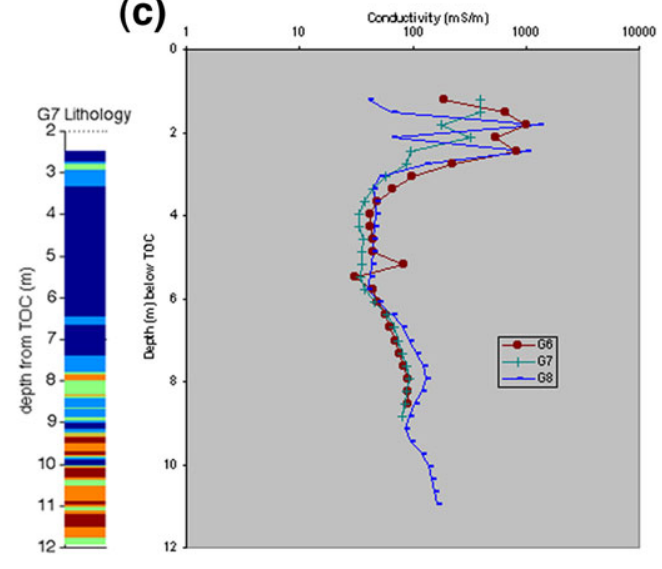

(b)

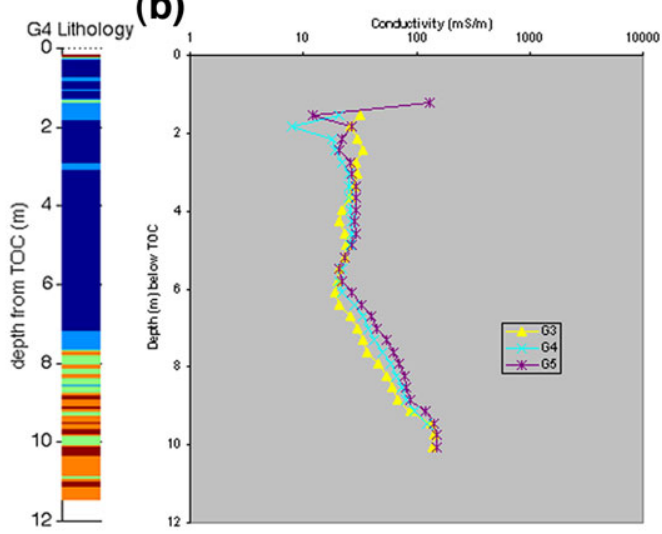

(d)

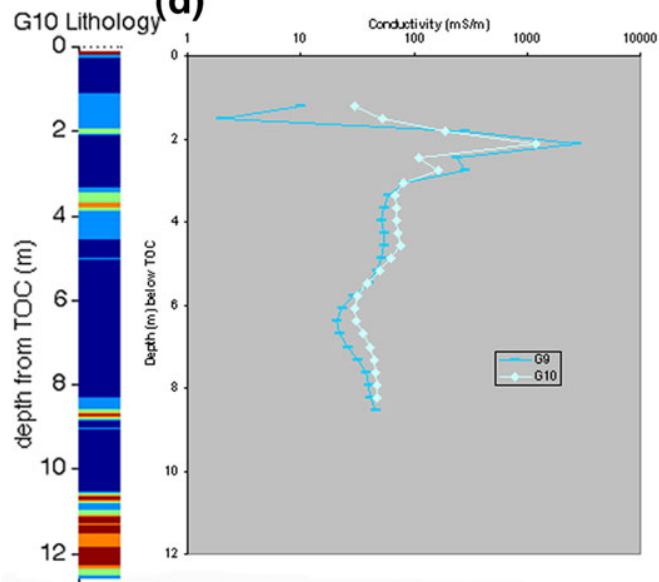

Figure 15. Borehole conductivity and CPT-derived lithology (1) G1, G2, (b) G3, G4, G5, (c) G6, G7, G8, (d) G9, G10. 


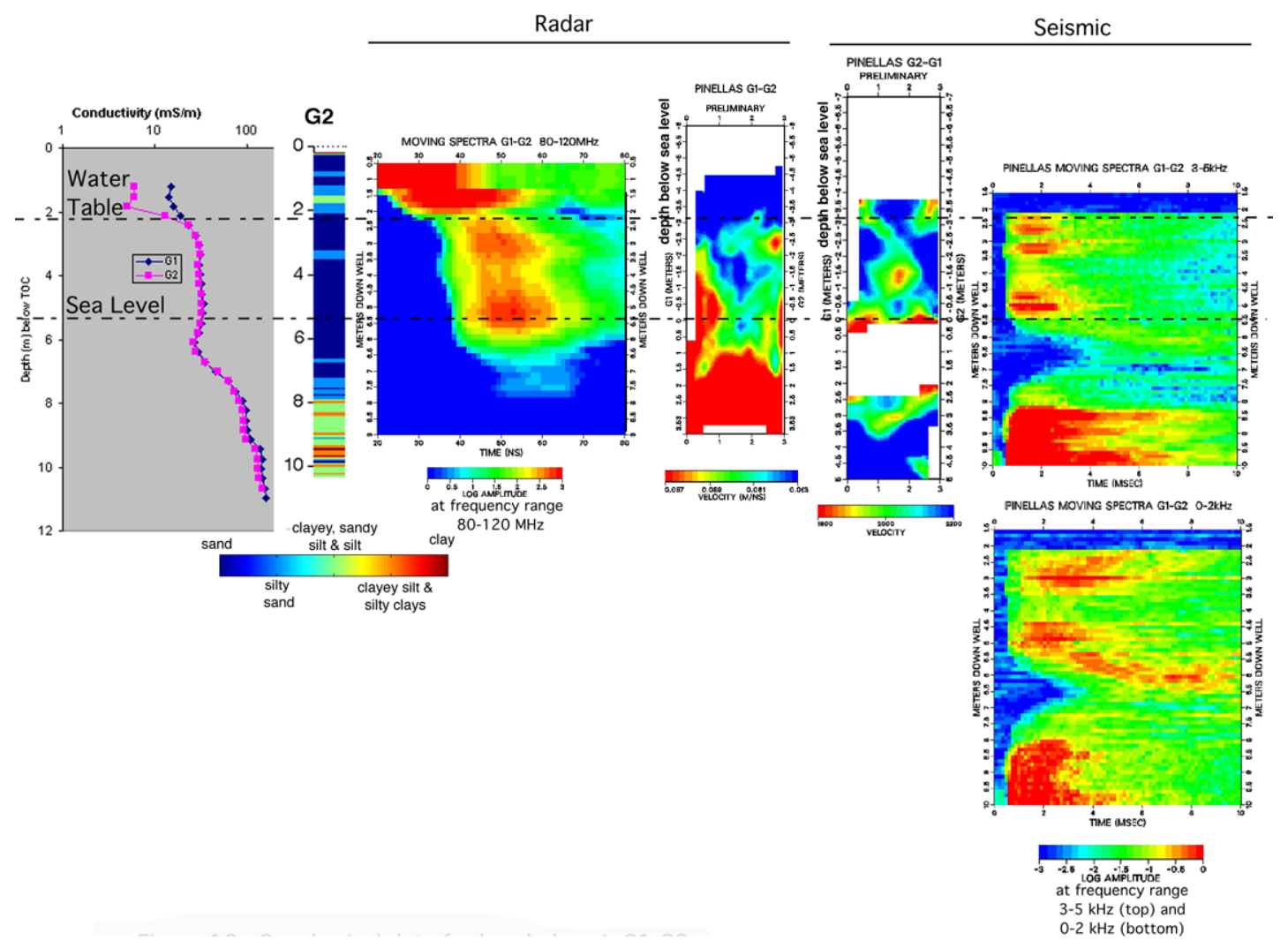

Figure 16. Geophysical data for borehole pair G1-G2. 


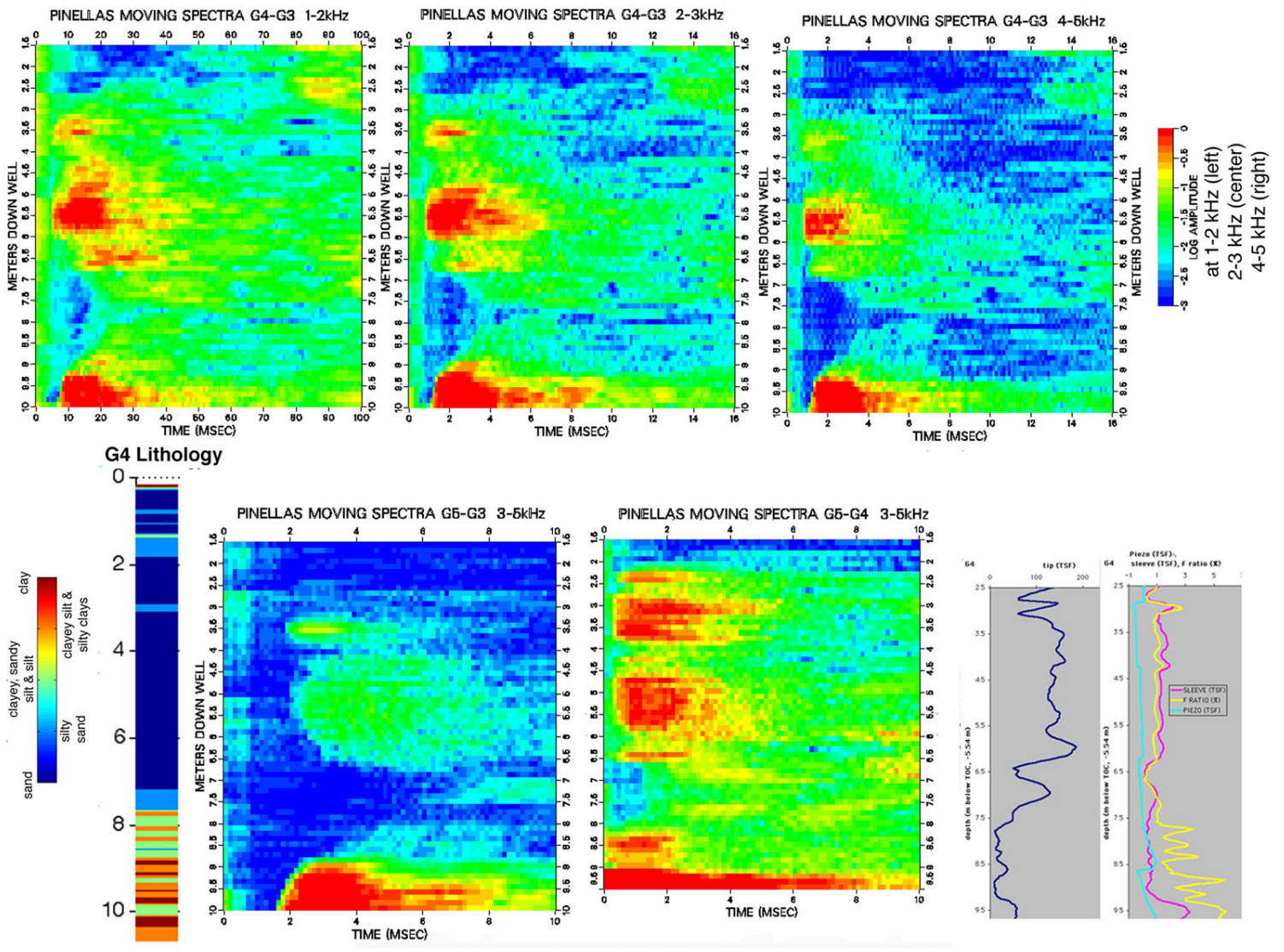

Figure 17. Seismic moving spectra data for G3-G4-G5. 


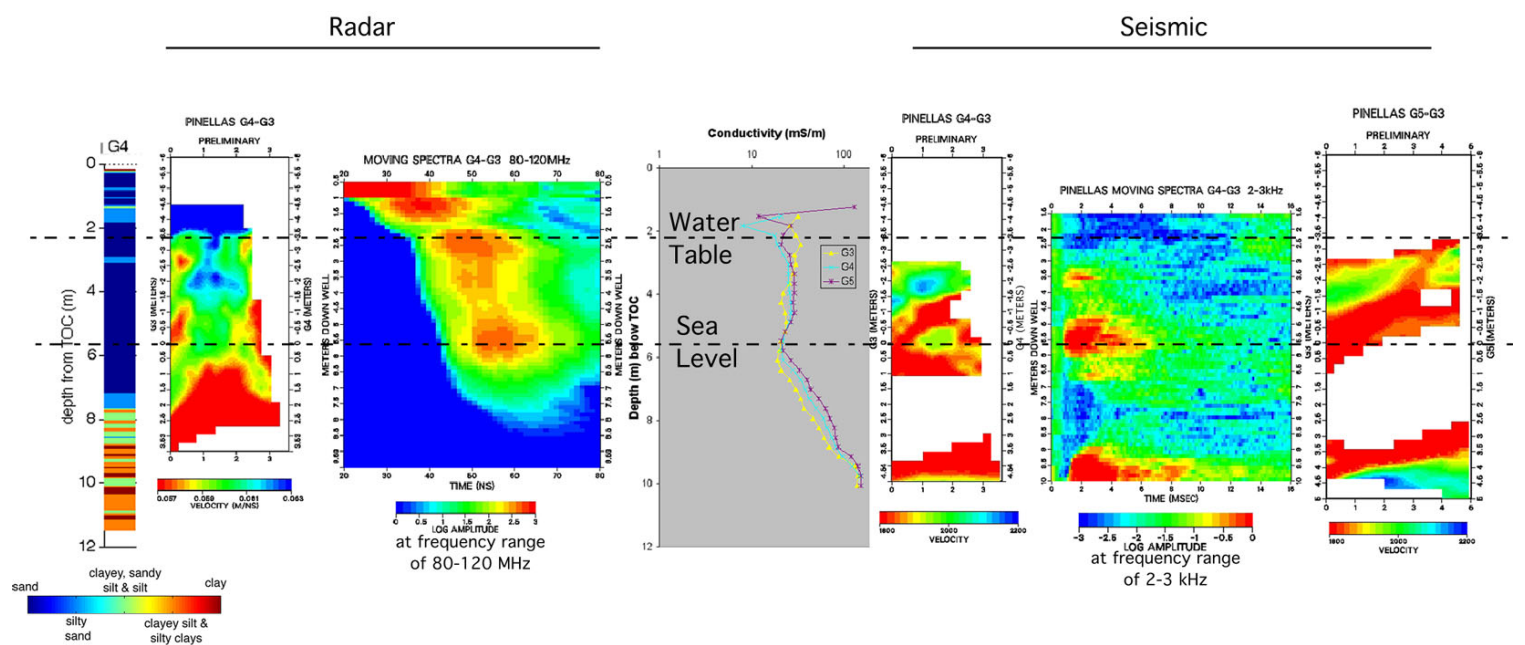

Figure 18. Geophysical data for G3-G4-G5.

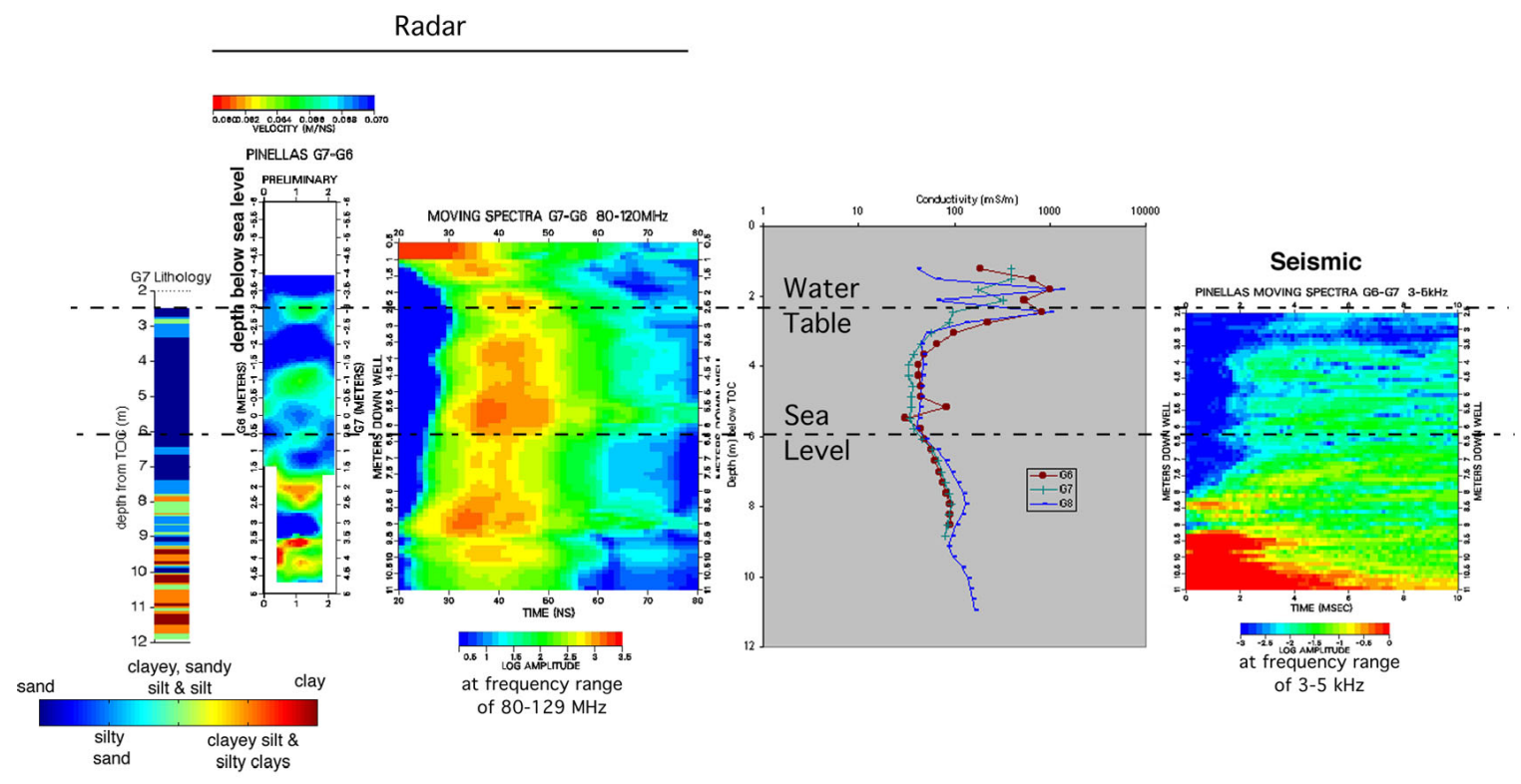

Figure 19. Geophysical data for G6-G7. 


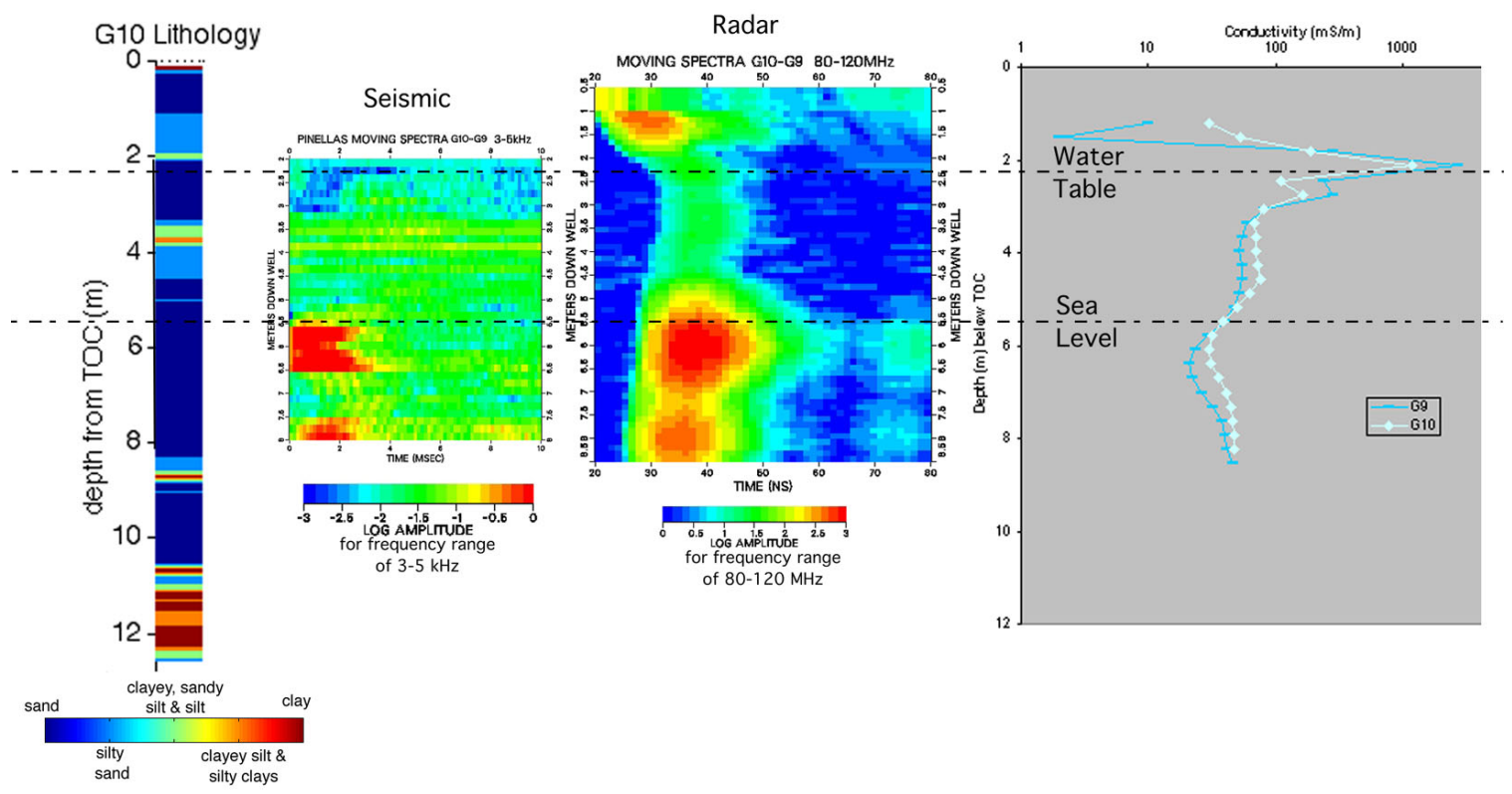

Figure 20. Geophysical data for G9-G10. 